\title{
Seismic performance of strengthened masonry structures: actual behaviour of buildings in Norcia and Campi Alto during the 2016 Central Italy seismic sequence
}

\author{
Romina Sisti $^{1}$ (D) Marco Di Ludovico ${ }^{1}$ (D) $\cdot$ Antonio Borri $^{2} \cdot$ Andrea Prota $^{1}$ (D
}

Received: 30 March 2021 / Accepted: 9 October 2021 / Published online: 19 October 2021

(c) The Author(s) 2021

\begin{abstract}
The structural response of unreinforced masonry buildings designed for gravity load only or with reference to obsolete seismic provisions is widely studied in the literature in order to define proper strengthening strategies and solution to mitigate the seismic risk. However, the critical analysis of the effectiveness of past used strengthening solution is still lacking. To fill such gap, the present study deals with the evaluation of the seismic performances of buildings in Campi Alto struck by the 2016 central Italy seismic sequence. The behaviour of buildings in Campi Alto is compared with that of buildings in Norcia. A large part of the buildings in these two towns was strengthened between 1980 and 2000 during the reconstruction processes following previous earthquakes which occurred in 1979 and 1997. However, the strengthened buildings in Norcia reported limited damage while a significant and widespread level of damage was detected on several strengthened buildings in the hamlet of Campi Alto. This study focuses on the buildings in Campi Alto with the aim of investigating on the reasons of their unsatisfactory behaviour. Thus, the seismic action experienced by buildings in Norcia and Campi Alto is initially compared and the main vulnerabilities of these buildings are also evaluated. Then, 20 projects of strengthening interventions submitted to the Civil Engineering Department of the Umbria Region between 1984 and 2012 have been herein analysed and discussed in order to focus on the effectiveness of the strengthening solution adopted in the past. The analyses of such projects and of the empirical damage detected after the 2016 seismic sequence is a unique opportunity to derive useful information for future applications.
\end{abstract}

Keywords Post-earthquake damage $\cdot$ Usability $\cdot$ Strengthening interventions $\cdot$ Masonry buildings

Romina Sisti

romina.sisti@unina.it

1 Department of Structures for Engineering and Architecture, University of Naples Federico II, Naples, Italy

2 Department of Engineering, University of Perugia, Perugia, Italy 


\section{Introduction}

The damage analysis after significant earthquakes allows the identification of the vulnerability of different types of existing structures; thus, a seismic event represents an occasion to better understand the response of existing buildings and, consequently, to plan and carry out experimental and analytical studies aimed at defining new strengthening strategies and solutions or construction details to reduce the structural deficiencies.

Several studies available in literature focused on the structural response of unreinforced masonry buildings (Sayin et al. 2013, Ortega et al. 2017, Gautam et al. 2016) in case of seismic events. They commonly discuss and analyse the behaviour of existing buildings designed for gravity load only or with reference to obsolete seismic provisions. They evidenced the most critical aspects and vulnerability of such constructions, strongly promoting the development of analytical and experimental studies aimed at the evaluation of new construction techniques or strengthening solutions. Despite laboratory or in situ tests are commonly carried out to validate the effectiveness of a specific strengthening solution, it is very difficult to reproduce and simulate the different state and conditions typical of existing structures, especially in case of masonry buildings. Indeed, the structural characteristics of masonry buildings vary depending on the construction period and the geographical area in which they were built (i.e. type, shape and size of the units that make up the masonry; quality of the mortar; the pattern in which the units are assembled; masonry thickness; connections between orthogonal walls; distance between walls; dimensions and position of openings; type of horizontal structures; connections between vertical and horizontal structures...).

It is also necessary to consider that the current configuration of older masonry buildings is often the result of successive modifications, which make each building unique. A last factor is the maintenance level of the building that greatly influences its seismic response. In the laboratory it is often possible to test a strengthening technique only on selected types of buildings, or elements. Although the choice of the building/element to be tested is taken to be as representative and generic as possible, the application in real cases will affect buildings/elements which may have a different behaviour than the one analysed in the laboratory, for the many variation factors listed above. Only a large-scale application of the analysed technique and the evaluation of its effectiveness following real seismic events can reveal any problems related to specific situations. However, it has rarely been possible to evaluate the real seismic response of a significant number of strengthened masonry structures to date: a recent study on the effectiveness of strengthening solution adopted in the reconstruction process of past earthquakes has been carried out by the authors (Sisti et al. 2018; Borri et al. 2018). It focuses on the structural response of masonry buildings in the historic centre of Norcia after the central Italy 2016 seismic sequence. The seismic sequence struck four regions of central Italy (Abruzzo, Lazio, Marche, Umbria) during 2016 and 2017; it was discussed in several studies focusing on: seismological aspects (Chiaraluce et al. 2017; Lanzo et al. 2019; Iervolino et al. 2019); behaviour and damage of residential buildings (Fiorentino et al. 2018; Sorrentino et al. 2018), of heritage buildings (D'Altri et al. 2018; Poiani et al. 2018), churches (Penna et al. 2019; Hofer et al. 2018), schools (Di Ludovico et al. 2018; Gara et al. 2017) and infrastructures (Callisto e Ricci 2019).

In Sisti et al. 2018 and Borri et al. 2018, the study evidenced that the structures in the historic centre of Norcia, renovated between 1980 and 2000 during the reconstruction 
processes following previous earthquakes occurred in 1979 and 1997, showed a good response to seismic sequence actions and reported very limited damage.

The present study analyses the empirical damage detected on the buildings of Campi Alto, a small medieval village few kilometers far from Norcia. Although most of the buildings were strengthened in the period 1980-2000, as in the case of Norcia, and in compliance with the same structural code, these buildings showed a very heterogeneous level of damage, from the slight damage to the collapse. In order to investigate on the reasons of the different behaviour of strengthened buildings in Campi Alto and Norcia, the present study analyses the differences between the two historic centres both in terms of terrain orography and structural characteristics of the buildings and, in particular, it focuses on the analysis of the construction details adopted in the strengthening interventions. The investigation involves the analysis of the data collected through the first level survey forms (AeDES) concerning post-earthquake damage and usability assessments (Baggio et al. 2007); the survey forms were filled after the 2016 and 2017 seismic sequence by the technicians of the Umbria Seismic Risk Office, coordinated by the Italian Civil Protection Department; the fact that the inspectors were part of the same Office and were limited in number should have reduced the variability in the assessment of damage (Steimen et al 2004). These data have been integrated by those derived by detailed in situ investigation. Furthermore, the study of the buildings characteristics and strengthening interventions has been integrated by analysing in detail 20 strengthening projects, submitted starting from the 1980s to the Civil Engineering Department of the Umbria Region, that affect the buildings in Campi Alto. This to fully correlate the damage detected after the seismic sequence to the buildings' characteristics and details of strengthening solutions that may have strongly influenced the seismic response of such buildings.

\section{Historical sequence of earthquakes in Norcia and Campi Alto}

The present study focuses on the behaviour of strengthened masonry buildings located in Campi Alto and Norcia. The presence in this area of a significant number of buildings strengthened after the earthquake occurred in 1979 and 1997 and the occurrence of a recent seismic sequence represents a unique opportunity to analyse the effectiveness of prevention actions and the soundness of strengthening techniques adopted. To this goal, a preliminary analysis of the characteristics of the two locations under investigation is presented in this section.

Norcia is located at $600 \mathrm{~m}$ above the sea level near the connecting area between the Santa Scolastica plain, a fault-bounded intermountain basin, and the northern border ridges (Fig. 1a). The city was founded in the fifth century B.C. but the construction of the city walls dates back to the Middle Ages and the urban layout was modified several times after the strongest earthquakes that stuck the city.

Campi Alto is a part of the municipality of Norcia and it overlooks Val Castoriana and stands on the slopes of mount Macchialunga between 900 and $800 \mathrm{~m}$ above sea level. This village was originally built in the mid-thirteenth century and it still preserves the features of a medieval castle that owes its urban layout to the orography of the site, which presents a strong drop in height (around $100 \mathrm{~m}$ between the bottom and the top of the town). The main roads and the terraced buildings are developed on terracing plots, that follow the level curves of the mountain, joined by ramps and orthogonal stairs (Fig. 1b). More details about the construction typologies, typical building 

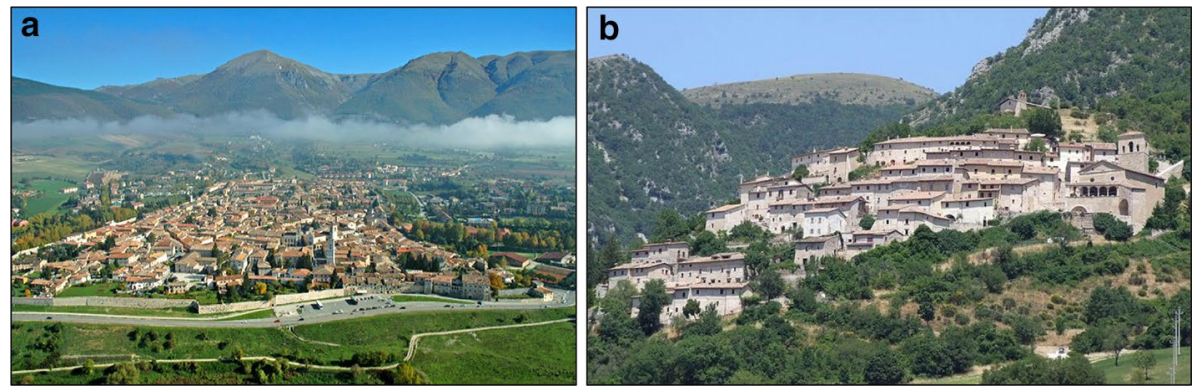

Fig. 1 Views of Norcia (a) and Campi Alto (b) before the 2016-2017 seismic sequence (pictures from websites www.umbriaoggi.it and www.iluoghidelsilenzio.it)

geometry, construction details and materials used in Campi Alto can be found in (Binda et al. 2007, 2006). The orography of the terrain has influenced the architectural characteristics of the buildings; they commonly develop on two or three levels (Fig. 2a). The first floor, originally used as cellar, store or stable, has access on the road facing downstream, while the last floor, is usually used as a living space. The rooms located on the ground floor were originally characterised by the presence of vaults (typically barrel vaults) and show walls carved straight into the rock.

The two settlements are part of Valnerina region (central Italy), a very active seismic zone. Figure 3 depicts the seismic histories of Campi Alto and Norcia, since 1800 and until the early 2000s (Rovida et al. 2019). The low number of events reported for Campi Alto is due to its smaller size and importance, compared to Norcia, that leads to a lack of information regarding the earthquake that struck this small, inhabited centre in the historical sources consulted for the construction of Italian Parametric Earthquake Catalogue.

Two main seismic events struck both Campi Alto and Norcia in 1859 and 1979. In Campi Alto, strengthening works carried out after the earthquake of 22th August 1859 are still visible: the downstream façades of most buildings are characterised by the presence of buttresses and spurs, mainly added because of that event. In Norcia, the current buildings' configuration originates from the structural code that drove the reconstruction projects following the 1859 earthquake. This technical document established several structural requirements, such as the minimum thickness of the walls or the maximum height of the buildings both for new buildings and in renovation works on existing ones. A detailed description of such structural code can be found in (Reale et al. 2004) and (Sisti et al. 2018).

In 1979 another earthquake with macroseismic intensity VIII in MCS scale, hit the area and caused significant damage. As reported in (Boschi et al. 1998), in Campi Alto 12 buildings were damaged, most of which were in poor condition before the earthquake, while Norcia was seriously damaged: few buildings partly collapsed and 44 strongly damaged buildings were demolished. After this event, a regional law (Regione Umbria 1981) was issued in order to define anti-seismic design procedures and suggest strengthening solutions to repair and improve the performances of structural elements. A detailed description of this regional law can be found in (Sisti et al.2018) and (Putrino and D'Ayala 2019a). A large part of the buildings in the historic centre of Norcia was renovated following this regional law, which has significantly influenced the current characteristics of the buildings (Fig. 2b). 

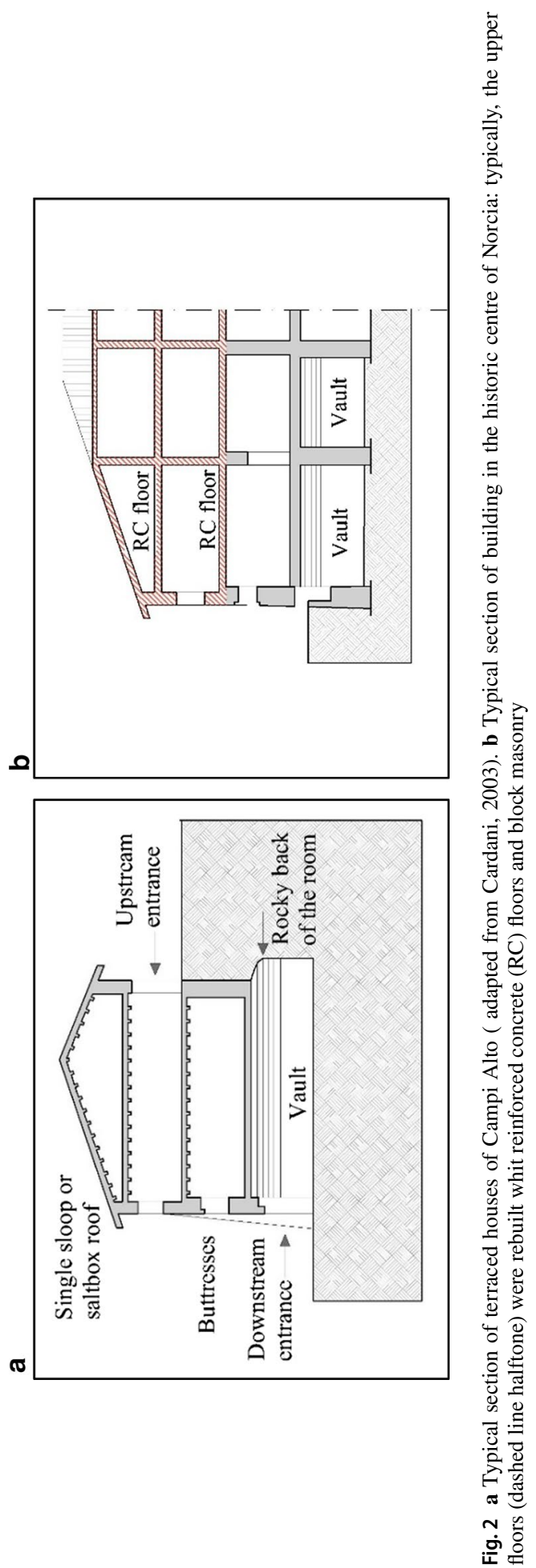


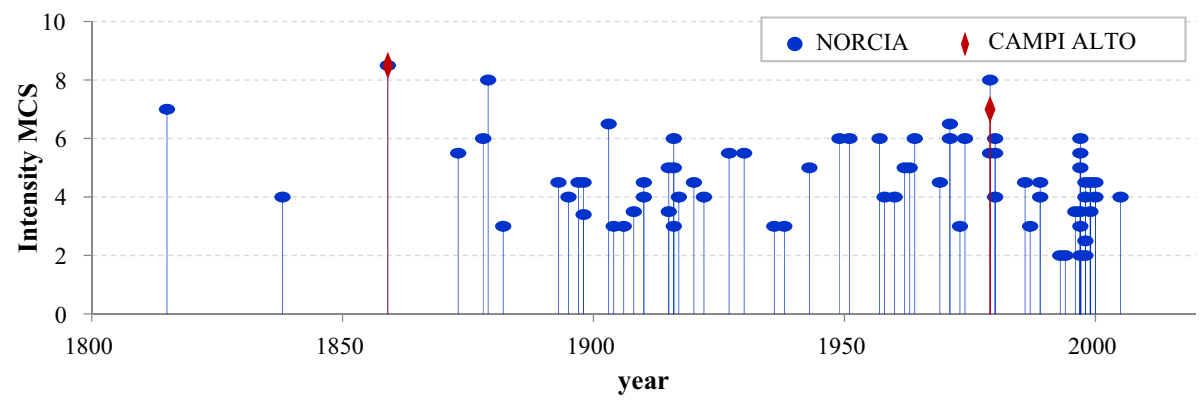

Fig. 3 Historical sequence of earthquakes in Norcia and Campi Alto in the period 1650-2000 (from Rovida et al. 2019)

In 1997, another earthquake hit an area slightly further North-West of Norcia and Campi Alto; given the low macro seismic intensity, only buildings in poor condition reported some damage.

\section{The 2016-2017 seismic sequence: analysis of seismic input in Campi Alto e Norcia}

The main shocks of the 2016-2017 seismic sequence of Central Italy are reported in Fig. 4 while Fig. 5 shows the two horizontal components of acceleration and pseudo-velocity response spectra obtained from the recordings of three accelerometric stations of the National Accelerometric Network (RAN) close to Campi Alto and Norcia. The processed strong-motion data are obtained from (Luzi et al 2016). The CMI station was $1 \mathrm{~km}$ far from Campi Alto (Fig. 6a) and thus its data can be considered representative of the seismic input of Campi Alto. This is a temporary station installed after the first earthquake of 24th August 2016 and, unfortunately, there are no records for the seismic event of the 30th October. The NOR e NRC stations are located in proximity of the historic centre of Norcia (Fig. 6b) and they are permanent accelerometers. The spectra are cut short at $2.5 \mathrm{~s}$ because the masonry structures analysed in this paper certainly have a lower principal period.

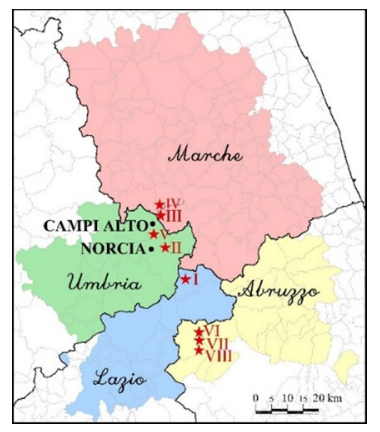

\begin{tabular}{|l|l|c|l|}
\hline $\begin{array}{l}\text { Main } \\
\text { shocks }\end{array}$ & Date and hour (Italy) & Mw & Epicenter \\
\hline$I$ & $24-08-2016 \quad 03: 36$ & 6.0 & Accumoli $(R I)$ \\
\hline$I I$ & $24-08-2016 \quad 04: 33$ & 5.3 & Norcia $(P G)$ \\
\hline$I I I$ & $26-10-2016 \quad 19: 10$ & 5.4 & Castelsantangelo sul Nera $(M C)$ \\
\hline IV & $26-10-2016 \quad 21: 18$ & 5.9 & Castelsantangelo sul Nera $(M C)$ \\
\hline V & $30-10-2016 \quad 07: 40$ & 6.5 & Norcia $(P G)$ \\
\hline VI & $18-01-2017 \quad 10: 25$ & 5.1 & Capitignano $(A Q)$ \\
\hline VII & $18-01-2017 \quad 11: 14$ & 5.5 & Capitignano $(A Q)$ \\
\hline VIII & $18-01-2017 \quad 11: 25$ & 5.4 & Capitignano $(A Q)$ \\
\hline
\end{tabular}

Fig. 4 Regions struck by the 2016-2017 seismic sequence in Central Italy: main shocks and Norcia and Campi Alto location 

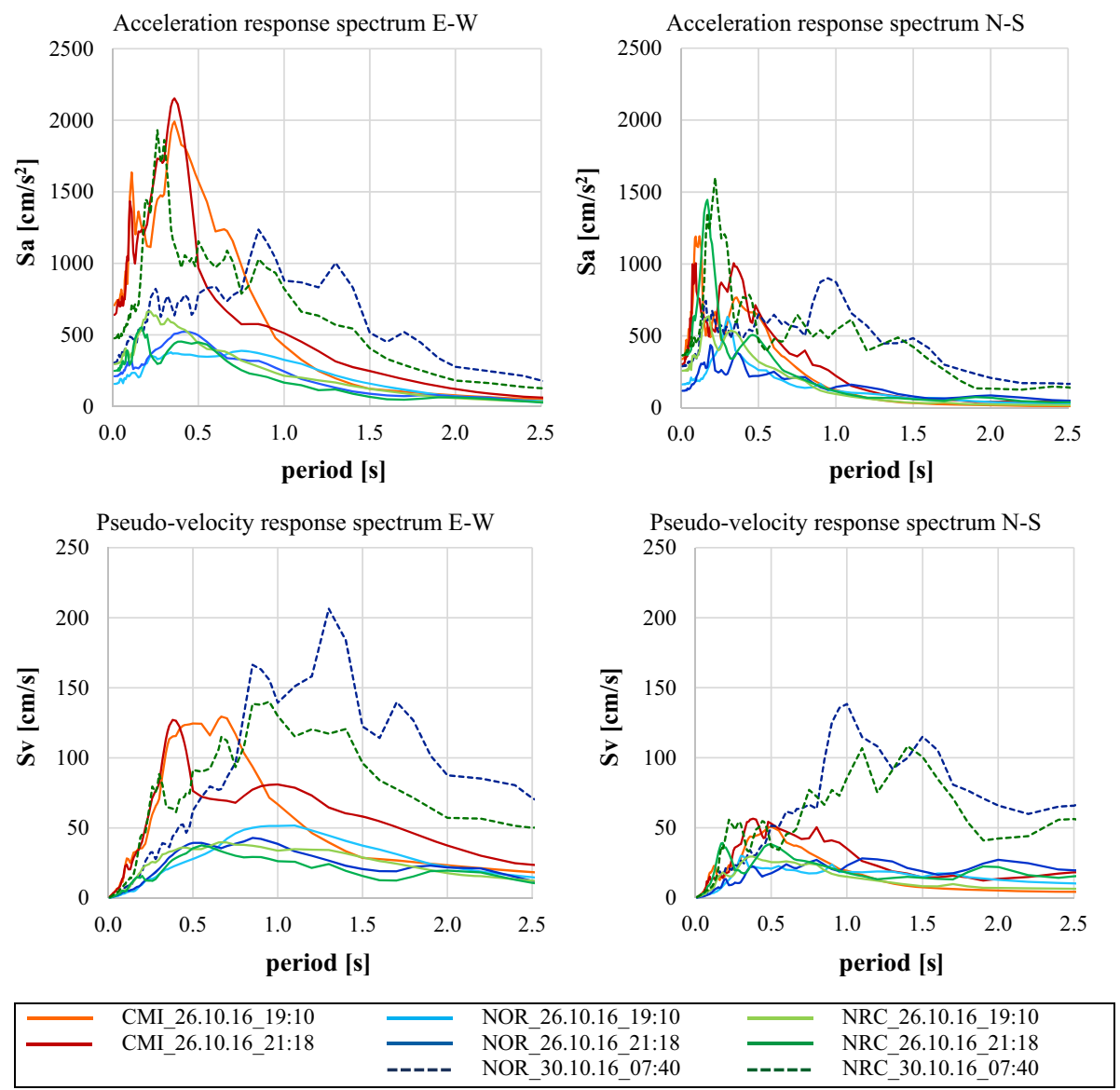

Fig. 5 Comparison of the acceleration response spectra and pseudo velocity response spectra recorded by three stations of the Italian Strong Motion Network during the earthquakes of 26th and 30th October 2016

\section{a}

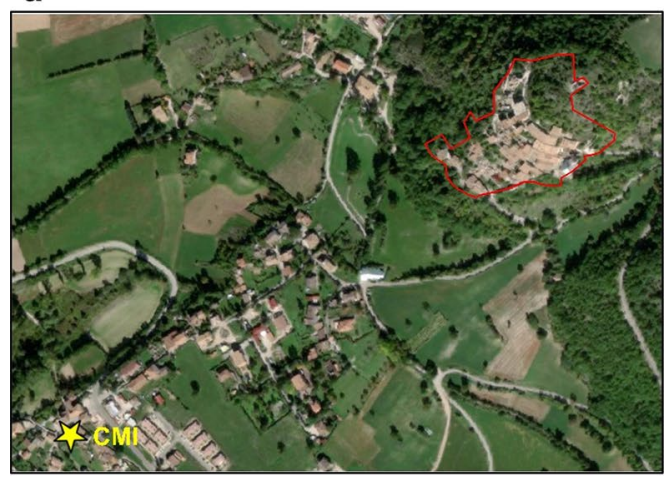

b

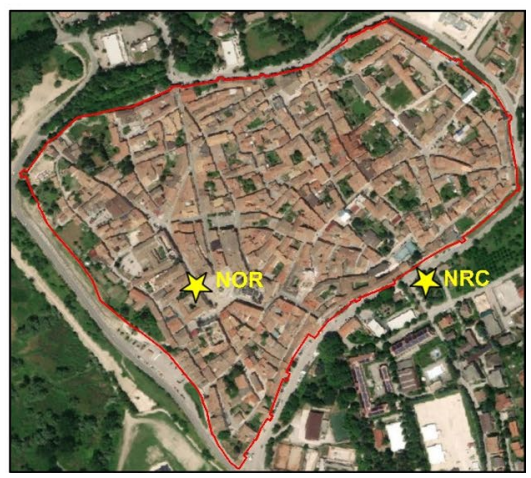

Fig. 6 Location of the three accelerometric stations considered in the study: a CMI station, $1 \mathrm{~km}$ far from Campi Alto (identified by the red line); b NOR and NCR stations in the historic centre of Norcia 
Table 1 summarizes the main parameters recorded by these three stations during the seismic sequence: the Peak Ground Acceleration (PGA), the acceleration corresponding to a period of $0.3 \mathrm{~s}$ (Sa_0.3), the maximum value of spectrum (Sa_max) and the corresponding period, the Peak Ground Velocity (PGV), the pseudo-velocity (Sv_0.3 s) corresponding to a period of $0.3 \mathrm{~s}$, and the maximum value of the pseudo-velocity spectrum $\left(\mathrm{S}_{\mathrm{v}-} \max \right)$. With reference to East-West seismic components, it is possible to note that for earthquakes actions occurred on 26th October, the CMI station recorded values significantly higher with respect to those of NOR and NRC stations, Fig. 5 and Table 1. With reference to the earthquake occurred on 30th October, for which only NOR and NRC station records are available, the most severe actions were recorded by NRC station. Both PGA $\left(707 \mathrm{~cm} / \mathrm{s}^{2}\right.$ versus $\left.476 \mathrm{~cm} / \mathrm{s}^{2}\right)$ and Sa_max $\left(1991 \mathrm{~cm} / \mathrm{s}^{2}\right.$ versus $\left.1931 \mathrm{~cm} / \mathrm{s}^{2}\right)$ were lower for NRC station with respect to $\mathrm{CMI}$; whereas the parameters corresponding to a period equal to $0.3 \mathrm{~s}$ were higher for NRC station. This clearly indicates that the seismic actions recorded in Campi Alto were higher or comparable to those recorded in Norcia.

Table 2 summarizes two other seismic intensity measures: the Housner Intensity, $I_{H}$ (Housner 1952), and the modified Housner intensity, $m I_{H}$ (Mouyiannou et al. 2014). They are calculated as integral of the pseudo-velocity spectrum between 0-2.5 and 0-0.5 s, respectively. These parameters are two energy-based intensity measures that may provide a better correlation with the structural damage with respect to parameters reported in Table 1 (Mouyiannou et al. 2014).

The trend of the parameters reported in Table 2 is similar to that of parameters in Table 1: during the earthquakes of 26th October, CMI station recorded higher values than those of the two stations close to Norcia; however, the values are fully comparable with those recorded by the NRC and NOR stations during the subsequent earthquake of $30^{\text {th }}$ October. In particular, some parameters (e.g. East-West component of $\mathrm{mI}_{\mathrm{H}}$ and PGA) was greater in Campi Alto but some others (e.g. East-West component of Sa_03 and North-South component of Sa_03, Sa_max, PGV and Sv_max) was greater in Norcia.

Several studies demonstrated that local seismic effects, due to soil properties and topography configuration, can significantly affect the response of structures (Jahromi and Karkhaneh 2019; Panzera et al. 2018). Thus, to understand if the different response of the buildings in the historic centre of Norcia and Campi Alto were affected by different amplification factors, the results of a seismic microzonation study, carried out after the 2016 earthquake by SGA (Studio Geologi Associati -Perugia-Italy), is depicted in Fig. 7.

In this study (available on website www.regione.umbria.it) a monodimensional model was adopted for Norcia, characterised by a flatten topographic surface, whereas in Campi Alto the presence of a complex morphology made it necessary to model the topographic amplification through a bidimensional analysis. Figure 7 reports three detailed maps describing the areal distribution of the Amplification Factor (AF) for three different period ranges: $0.1-0.5 \mathrm{~s}, 0.4-0.8 \mathrm{~s}, 0.7-1.1 \mathrm{~s}$. The centre of Norcia is totally characterised by an amplification factor in the range of 1.1-1.4, regardless of the period of the structures, whereas in Campi Alto two subzones with an amplification factor of 1 or in the range of 1.1-1.4 can be identified. Thus, the amplification factor computed on Campi Alto is in every case lower (or equal) than that related to the centre of Norcia. Indeed, although Campi Alto has a more unfavourable topographic condition than Norcia, the subsoil stratigraphy is better: the bedrock is rather shallow, while in Norcia there are thick layers of alluvial deposits.

Based on the results of the seismic microzonation study it is therefore possible to exclude that the different behaviour of the two settlements analysed is attributable to local amplification problems. 


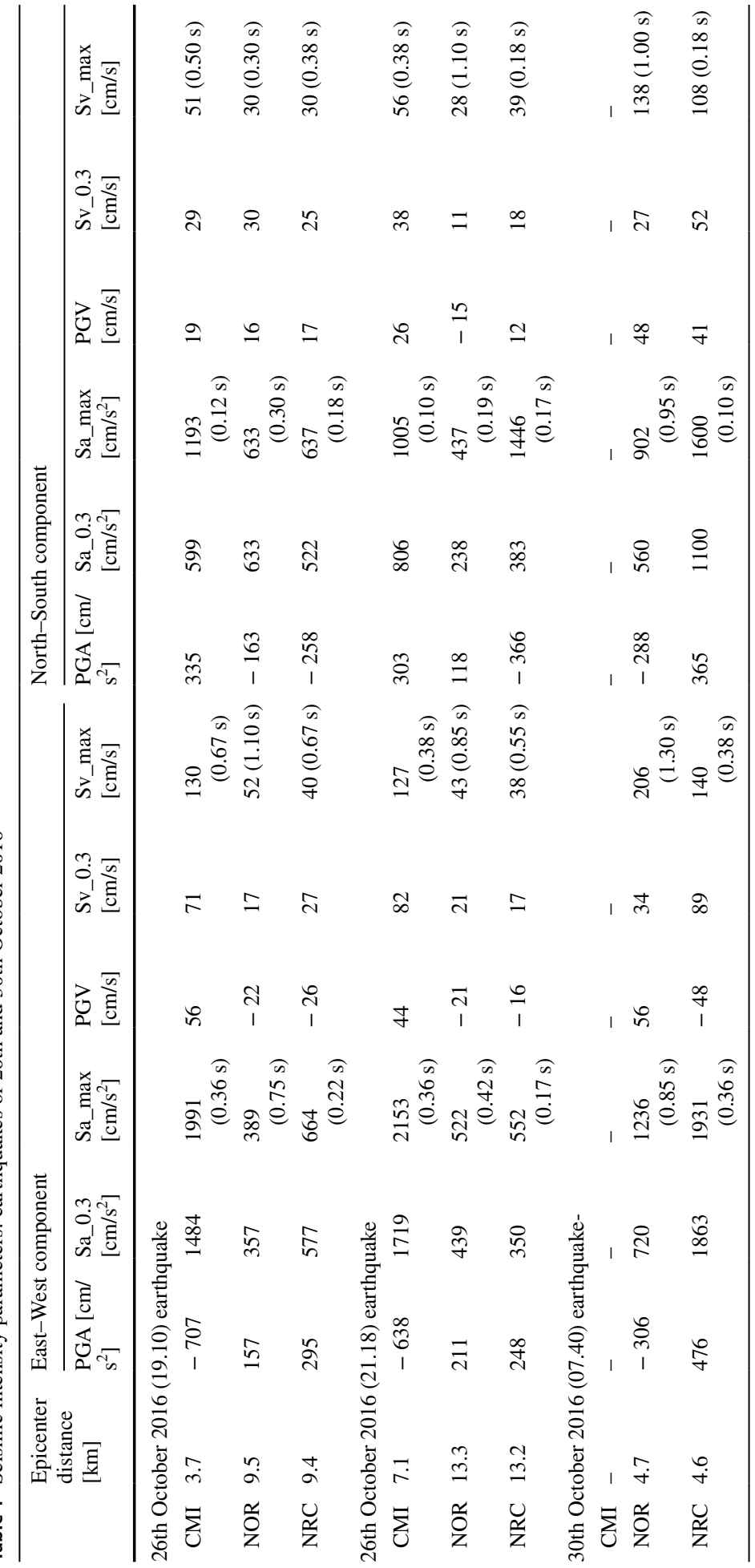


Table 2 Housner Intensity $\left(\mathrm{I}_{\mathrm{H}}\right)$ and modified Housner Intensity $\left(\mathrm{mI}_{\mathrm{H}}\right)$

\begin{tabular}{|c|c|c|c|c|}
\hline & \multicolumn{2}{|c|}{ East-West component } & \multicolumn{2}{|c|}{$\begin{array}{l}\text { North-South compo- } \\
\text { nent }\end{array}$} \\
\hline & $\mathrm{I}_{\mathrm{H}}[\mathrm{cm}]$ & $\mathrm{mI}_{\mathrm{H}}[\mathrm{cm}]$ & $\mathrm{I}_{\mathrm{H}}[\mathrm{cm}]$ & $\mathrm{mI}_{\mathrm{H}}[\mathrm{cm}]$ \\
\hline \multicolumn{5}{|c|}{ 26th October 2016 (19:10) earthquake } \\
\hline CMI & 130 & 31 & 41 & 13 \\
\hline NOR & 75 & 7 & 39 & 7 \\
\hline NRC & 65 & 10 & 40 & 9 \\
\hline \multicolumn{5}{|c|}{ 26th October 2016 (21:18) earthquake } \\
\hline CMI & 142 & 31 & 63 & 14 \\
\hline NOR & 62 & 9 & 51 & 5 \\
\hline NRC & 51 & 8 & 48 & 11 \\
\hline \multicolumn{5}{|c|}{ 30th October 2016 (07:40) earthquake } \\
\hline CMI & - & - & - & - \\
\hline NOR & 253 & 13 & 180 & 11 \\
\hline $\mathrm{NRC}$ & 204 & 23 & 151 & 16 \\
\hline
\end{tabular}

\section{Comparative analysis on structural characteristics and damage: buildings of Campi Alto and Norcia}

The comparative analysis of buildings characteristics in Campi Alto and Norcia is based on the data collected by in situ surveys and relevant AeDES forms (Baggio et al. 2007). The forms were filled by technicians of the Umbria Seismic Risk Office following the 2016 seismic sequence. The damage analysed in this paper is the total damage at the end of seismic sequence because available data do not allow the analysis of the damage evolution; specific analyses focusing on the effect of cumulative damage on the building stock are reported in (Putrino and D'Ayala 2019b).

In Campi Alto, 49 AeDES forms were analysed covering the total number of ordinary buildings inside the walls of the village: 44 masonry structural units (MSUs) of residential buildings and 5 warehouses. By contrast, the data related to buildings in the centre of Norcia involve $670 \mathrm{MSUs}$ but they are not the total number of buildings (i.e. a significant percentage of about $80 \%$ ).

Figures 8 and 9 show the percentage of MSUs as a function of age of construction (C) and renovation (R), masonry quality, type of horizontal structures, and roof type. Note that the year 1982 has been considered as a reference year to have preliminary indications on the seismic capacity of buildings. Indeed, after the completion of the reconstruction following the 1859 earthquake there were very few new buildings, while the construction of new buildings was significant in Norcia in the post-1979 reconstruction. For this reason, if a building was not rebuilt after 1979, it is very likely that it dates back to 1860 or even earlier. Note that UR (unreinforced) means that no renovation works were recorded.

The majority of MSUs (65\% and 60\% for Campi Alto and Norcia, respectively) has been built before 1982 and strengthened after this date. However, there are no MSUs dated after 1982 in the sample related to Campi Alto. Thus, only few MSUs in Campi Alto (6\%) have regular layout/good quality masonry, while 55\% show irregular layout/bad quality masonry and $29 \%$ is characterised by both qualities of masonry (namely "mixed"). By contrast, the quality of masonry of MSUs in Norcia is evenly spread in the sample: regular layout/good quality masonry (27\%), mixed (34\%) and irregular layout/bad quality masonry 


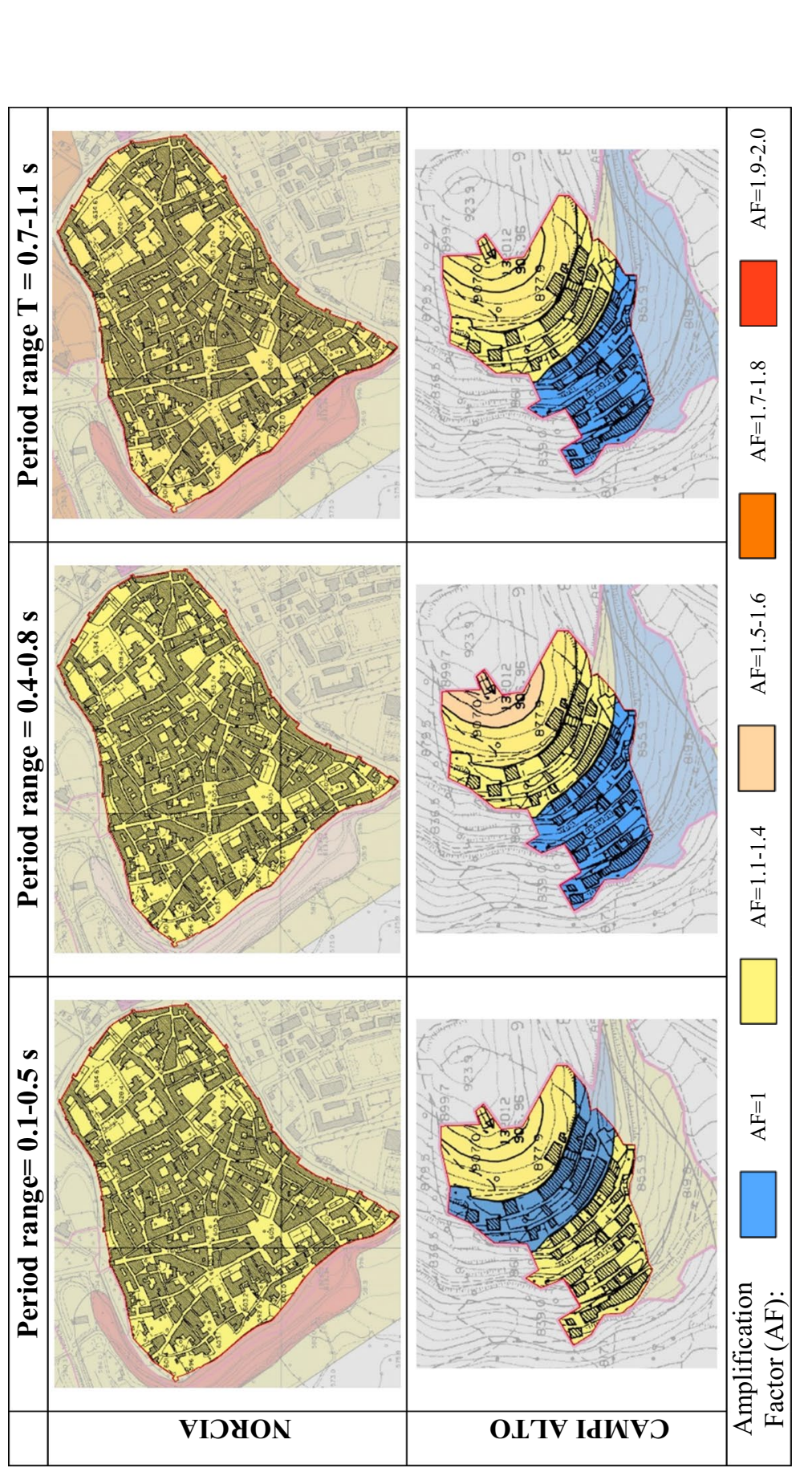

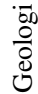

50
0
0
0
0
0
0
0
0
0

U్ర

호

$\bar{\Xi}$

$\stackrel{\Xi}{\mathscr{E}}$

$\frac{\pi}{3}$

ż

4

:ํㅗำ

䒕

:

$\ddot{\circ}$

종

点

$\stackrel{2}{ \pm}$

ह

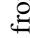

$\stackrel{\circ}{2}$

हี

Uี

E

흉

Z

प

苞

흥

근

䒿

产

$\sum$

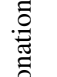

:

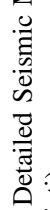

ธิ

ํํㄴ 


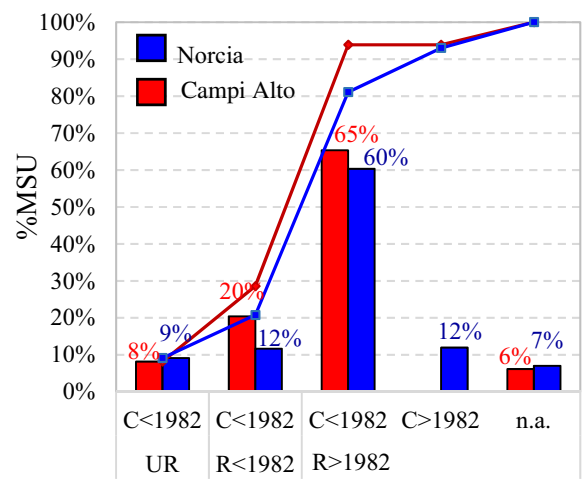

Age of construction (C) and Renovation ( $R$ )

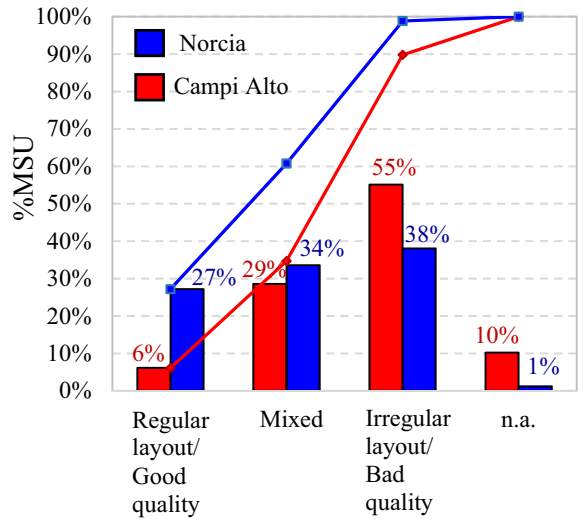

Masonry quality

Fig. 8 MSUs in Campi Alto (red) and Norcia (blue): percentages and cumulative trends as a function of age of construction and renovation and masonry quality

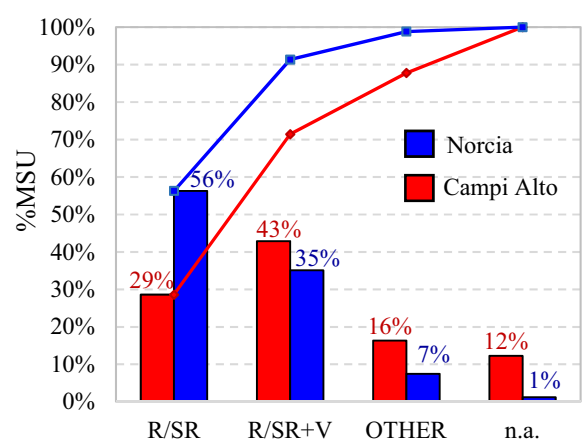

Type of horizontal structures

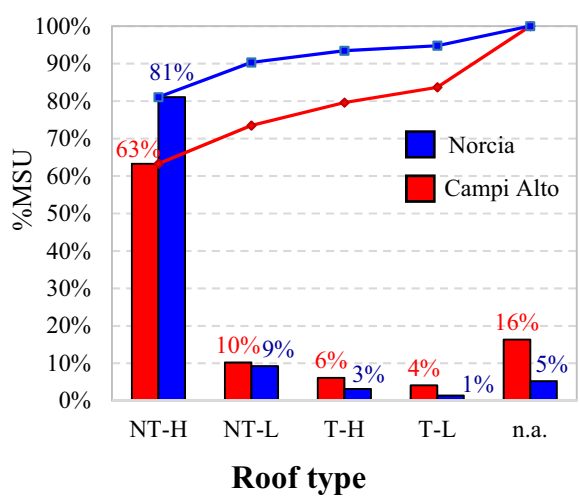

Fig. 9 MSUs in Campi Alto (red) and Norcia (blue): percentages and cumulative trends as a function of type of horizontal structures and roof type

(38\%). Figure 10 reports a comparison between Campi Alto and Norcia typical masonry types. The masonry of buildings in Campi Alto generally consists of rough stone elements (generally limestone, conglomerates, or travertine). It is commonly strongly irregular, and it is rarely possible to recognise the presence of horizontal bed joints (Fig. 10a, b). Furthermore, in several cases the masonry is made by disconnected layers, small elements and powdery mortar with lack of any cohesiveness. By contrast, the masonry of buildings in Norcia is mainly characterized by worked stone elements placed in a regular way (Fig. 10c, d). However, in some cases also in Norcia irregular masonry can be found as depicted in Fig. 10e. Furthermore, buildings of Norcia are commonly plastered.

The difference of MSUs in Campi Alto and Norcia is related not only to the masonry quality but also to the type of horizontal structures. Buildings in Norcia mostly presents beams with Rigid or Semi-Rigid (R/SR) slabs on each floor (i.e. $56 \%$ of the dataset) while in Campi Alto this kind of horizontal structures are often limited to the upper floors and on the ground floor there are Vaults (R/SR $+V$ in Fig. 9). Finally, in terms 
a
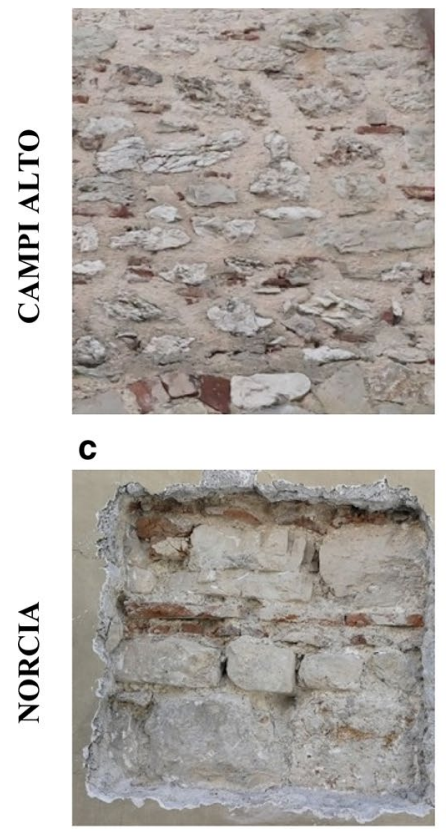

b

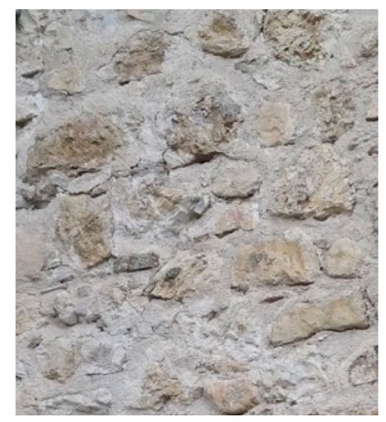

d

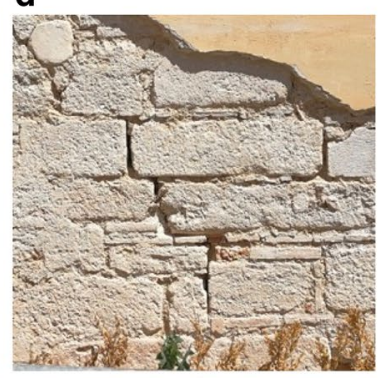

e

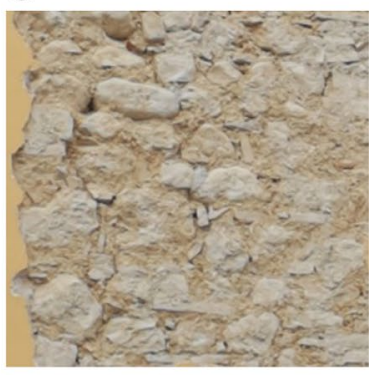

Fig. 10 Comparison between masonry types observed in Campi Alto (a, b) and in the historic centre of Norcia (c, d, e)

of roof types, the most significant difference between Campi Alto and Norcia is related to the presence of Non-Thrusting Heavy structures (NT-H), 63\% and $81 \%$ of the MSUs dataset for Campi Alto and Norcia, respectively. Non-Thrusting Light (NT-L) roofs represent $10 \%$ and $9 \%$ of the dataset for Campi Alto and Norcia while Thrusting Light (T-L) and Thrusting Heavy $(\mathrm{T}-\mathrm{H})$ roofs are uncommon.

Figure 11 summarizes the structural features of the buildings: six structural classes are identified based on masonry quality (good or bad quality), the presence of strengthening interventions on vertical structures and the type of horizontal structures (vaults, beams with flexible slabs, beams with semi-rigid or rigid slabs).

In the AeDES form (Baggio et al. 2007) different usability ratings are reported: A. Usable buildings; B. Building usable only after short term countermeasures; C. Partially usable building; D. Temporary unusable building requiring a more detailed investigation; E. Unusable building.

Usability rating is related to the damage of structural components (vertical, horizontal, stairs, roof) and non-structural components.

Figure 12a shows that in Campi Alto 92\% of the residential MSUs (45 MSUs) resulted unusable (E rating), and the remaining 8\% (4 MSUs) usable only after short term countermeasures or partially usable (B/C rating). In Norcia, the percentage of usable MSUs (A rating) was strongly greater than in Campi Alto and equal to $26 \%$ of MSUs; the remaining part was almost equally distributed in B/C or E rating $(42 \%$ and $32 \%$, respectively). This clearly indicate a better response of MSUs in Norcia with respect to Campi Alto. 


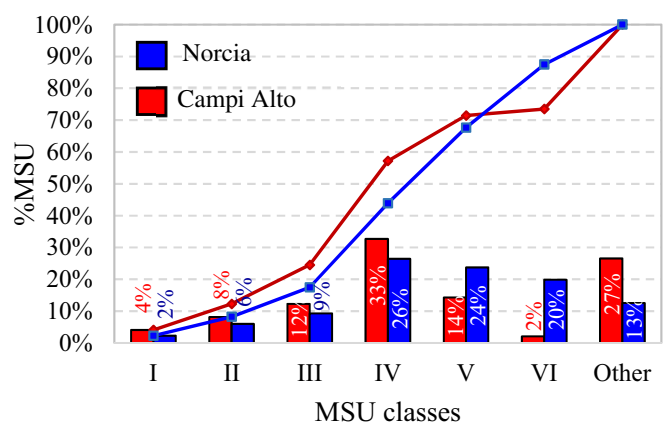

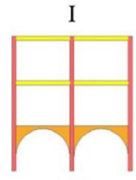

IV

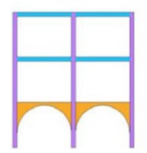

TYPE OF MASONRY:

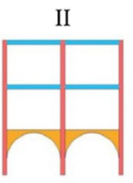

$\mathrm{V}$

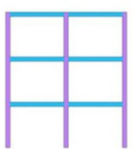

Bad quality, never strengthened. Bad quality, strengthened. Good quality

HORIZONTAL STRUCTURES: Vaults

Beams with flexible slabs

Beams with semirigid or rigid slabs

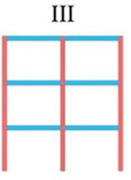

VI

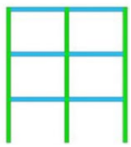

Fig. 11 MSUs classes

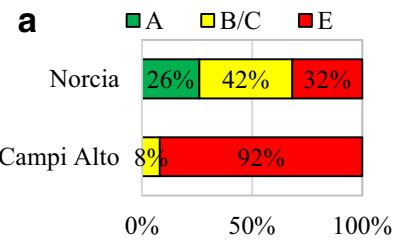

b $\square$ DI 0 DI 1 aDI 2 aDI 3 घD4 $\square$ DI 5 an.a.

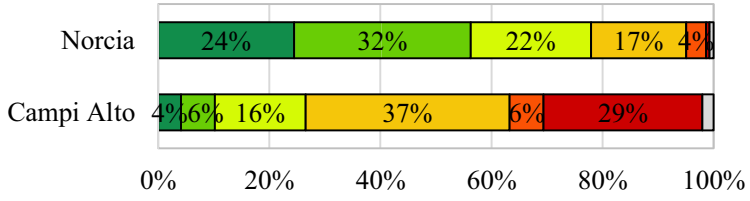

Fig. 12 Usability ratings (a) and Damage Index, DI, (b) of MSUs in Norcia and Campi Alto

To better understand the differences in the behaviours of the MSUs, the damage on vertical structures reported in the AeDES form is analysed. The AeDES form allows to indicate the complete absence of damage or the presence of light, medium-severe and very heavy damage as well as their extent with respect to the totality (both internal and external) of the load-bearing walls in the MSU: lower than $1 / 3$, between $1 / 3$ and $2 / 3$, greater than $2 / 3$. The many possible combinations were condensed into a simpler Damage Index (DI) according to the correlation matrix proposed in (Dolce et al 2019). The damage index ranges between 0 and 5 and follows the damage grades of the European Macroseismic Scale (EMS-98) (Grünthal 1998).

Typically, the group of "unusable" buildings includes a very wide range of damage: from the destroyed building (damage index equal to 5) to the building in which the damage modifies its response to a possible aftershock of similar intensity to that of the event that caused the damage (damage index equal to 2). In other cases, the usability may not represent the global behaviour of the building because it is related to local damage. Thus, to specifically refer to the structural damage, the damage index has been used in the analyses to classify the actual damage conditions.

The percentages of DI levels related to Norcia and Campi Alto are depicted in Fig. 12b. The figure clearly confirms that a more severe level of damage was detected on MSUs of Campi Alto with respect to Norcia: a DI lower or equal to 2 was detected on $78 \%$ of MSUs in Norcia against 26\% in Campi Alto. Furthermore, in Campi Alto 29\% 
of MSUs resulted affected by local or global collapse, DI 5. The plan distribution of DI in Campi Alto and Norcia is reported in Fig. 13. In Campi Alto a higher concentration of buildings with DI equal to $4-5$ is found in the lower part of the town. Comparing this map with the seismic microzonation map (Fig. 7) for buildings with a period of $0.1-0.5 \mathrm{~s}$, it is observed that the lower part of the town is characterized by an AF of 1.1-1.4, while the upper part of the town has an AF equal to 1. When the MSU is part of a terraced building, consisting of several adjacent MSUs, its position in the compound of units does not seem to have a clear correlation with the damage index.

Figure 14 reports the cumulative percentages of MSUs with a DI lower than a fixed value. In particular, the trends are plotted with reference to MSUs built after 1982 $(\mathrm{C}>1982)$ or before such year $(\mathrm{C}<1982)$ but renovated before or after $1982(\mathrm{R}<1982$; $\mathrm{R}>1982$ ) or unreinforced (UR). It is noticeable that in Campi Alto $80 \%$ of the MSUs renovated after 1982 has a damage index lower than or equal to 3 (usually only local damage), while those renovated before 1982 reach the $50 \%$ mark. All the unreinforced MSUs had a damage index equal to 5 .

For the dataset of MSUs in the historic centre of Norcia, it resulted that $97 \%$ of MSUs renovated after 1982 and about $95 \%$ of those renovated before 1982 show a damage index equal to or lower than 3 .

Furthermore, according to AeDES forms and in situ inspections specifically carried out by the authors resulted that in Campi Alto 13 MSUs collapsed (i.e. 9 full collapse and 4 partial collapse, see Fig. 15), corresponding to $26 \%$ of the entire built-up area. In particular, the full collapses affected 4 MSUs never consolidated, 4 renovated before 1982, and 1 renovated after 1982 while 4 partial collapses affected MSUs renovated after 1982. In Norcia, only 4 MSUs collapsed and 7 partially collapsed corresponding to about $2 \%$ of the dataset.

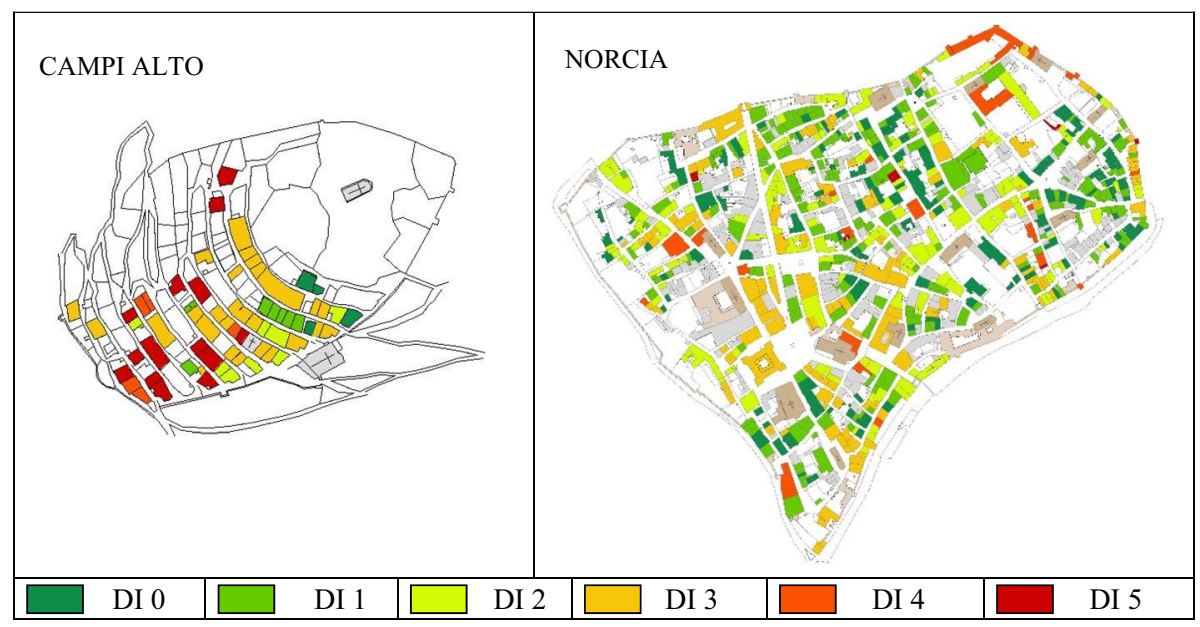

Fig. 13 Maps of Campi Alto and the historic centre of Norcia: identification of the damage index rating of residential buildings 


\section{C $<$ 1982; UR}

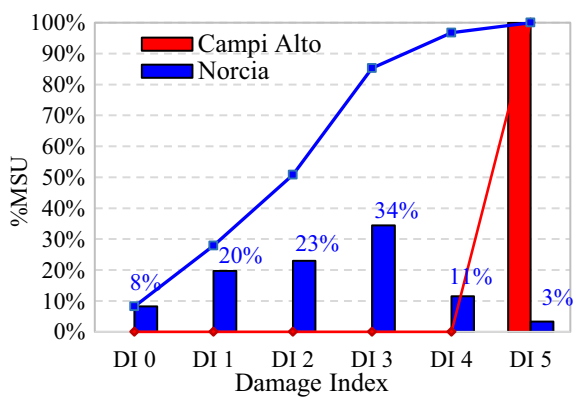

$\mathrm{C}<1982 ; \mathrm{R}>1982$

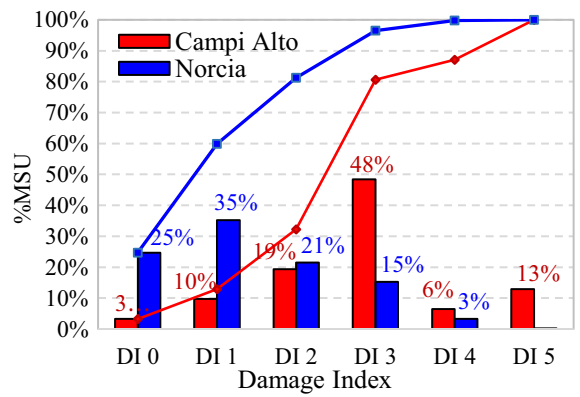

$\mathrm{C}<1982 ; \mathrm{R}<1982$

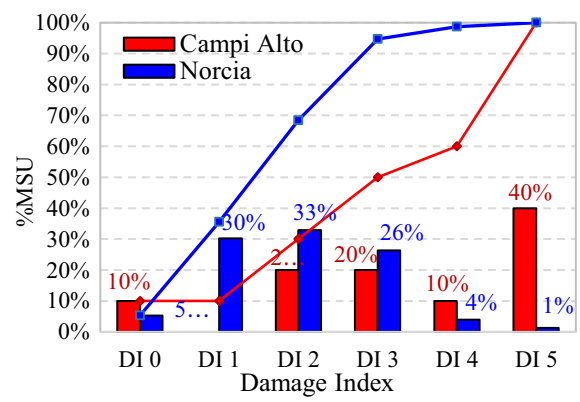

C $>1982$

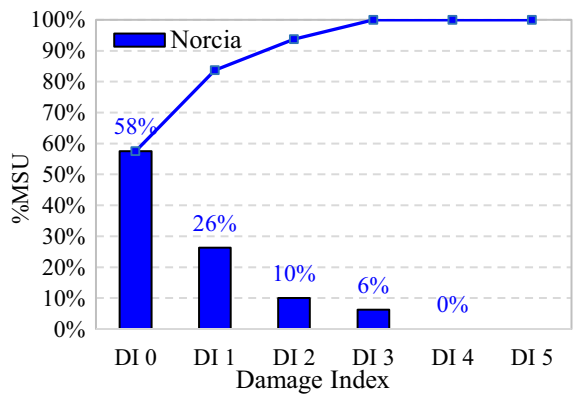

Fig. 14 Influence of the age of construction (C) and renovation works (R) on the damage index (DI) distribution (bar plots). The continuous lines represent the cumulative percentage of MSUs that attained a DI equal to or lower than a given value

\begin{tabular}{|c|c|c|}
\hline Legend & CAMPIA ALTO & NORCIA \\
\hline Collapse & & \\
\hline & & \\
Partial collapse & & \\
& & \\
& &
\end{tabular}

Fig. 15 Maps of Campi Alto and the historic centre of Norcia: identification of total and partial collapses in residential buildings

\section{Critical analysis of strengthening intervention effectiveness}

The data discussed in the previous sections show that, even if most of MSUs in Campi Alto and Norcia were renovated following the 1979 seismic events, the damage caused by the 2016 seismic sequence was more severe in Campi Alto with respect to Norcia. 
The worst behaviour of the buildings in Campi Alto can be attribute to their highest vulnerability (i.e. irregularity in elevation, poor masonry quality) but also to a lack of care in construction details and the presence of restrictions in the strengthening interventions to preserve the original appearance of the buildings. To focus the issues of strengthening interventions, a detailed analysis of 20 strengthening projects realized in Campi Alto between 1984 and 2012 is herein reported. The 20 projects involve 26 MSUs highlighted in purple in Fig. 16, corresponding to 53\% of the entire built-up area of Campi Alto. Thus, the sample of data may be reasonably representative of the strengthening works carried out in Campi Alto. The different number of projects and MSUs is because some projects involve more than one MSU. The original documentation has been examined thanks to the collaboration with Umbria Region Offices. A summary of building characteristics (number of stories and average floor surface) and of relevant strengthening intervention data (year of project of the intervention, type of the intervention on vertical and horizontal structures) as well as details on empirical damage detected after the last seismic sequence (damage index and type of external damage) on such MSUs is reported in the Annex section.

Figure 17 shows the distribution of the damage index evaluated according to the data collected in the post 2016 earthquake sequence by AeDES form. The 26 MSUs have been grouped in three categories based on the type of external damage detected during in-situ inspections carried out by authors: MSUs with no external damage (N.E.D.); MSUs with external damage (E.D.); and partially collapsed MSUs (P.C.). Note that during the in-situ inspections carried out by the author, it was possible only to evaluate the external condition of the buildings, whereas the AeDES data also considers the internal damage (unless the building was inaccessible); for that reason, also within the group "no external damage" $50 \%$ of MSUs has a damage index equal to 3.

In general, the analysis of the documentation related to the 26 MSUs (see Annex) showed that the intervention on vertical structures commonly involved the replacement of existing vertical walls of the floors above ground floor, combined with strengthening of undemolished walls portions by using several solutions: grout injections (G.I.), reinforced plaster jacketing (R.P.), steel connectors (S.C.) and tie roads (T.R.). In particular, G.I. was often combined with a wide use of S.C. at the orthogonal wall intersections. The R.P. was used to strengthen the bearing walls in only 6 projects, however this intervention rarely

Fig. 16 Strengthened MSUs in Campi Alto under investigation

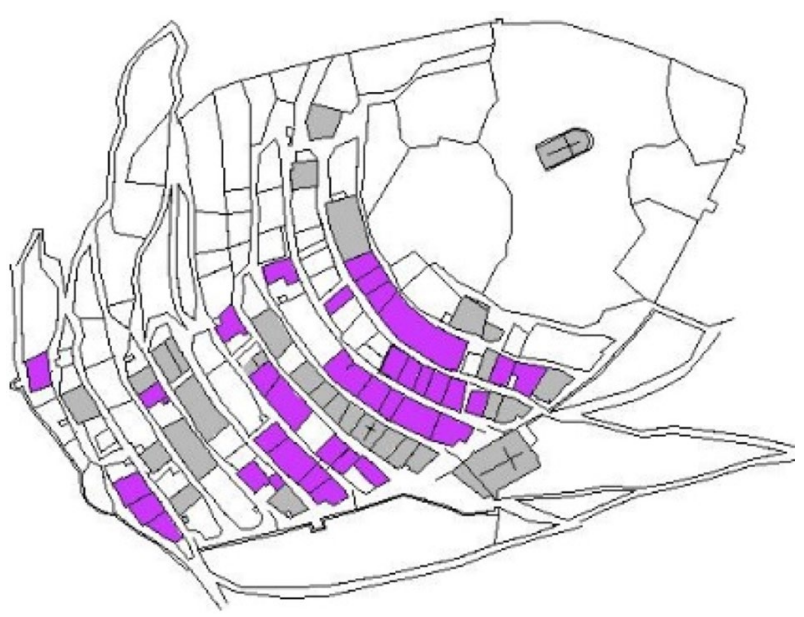




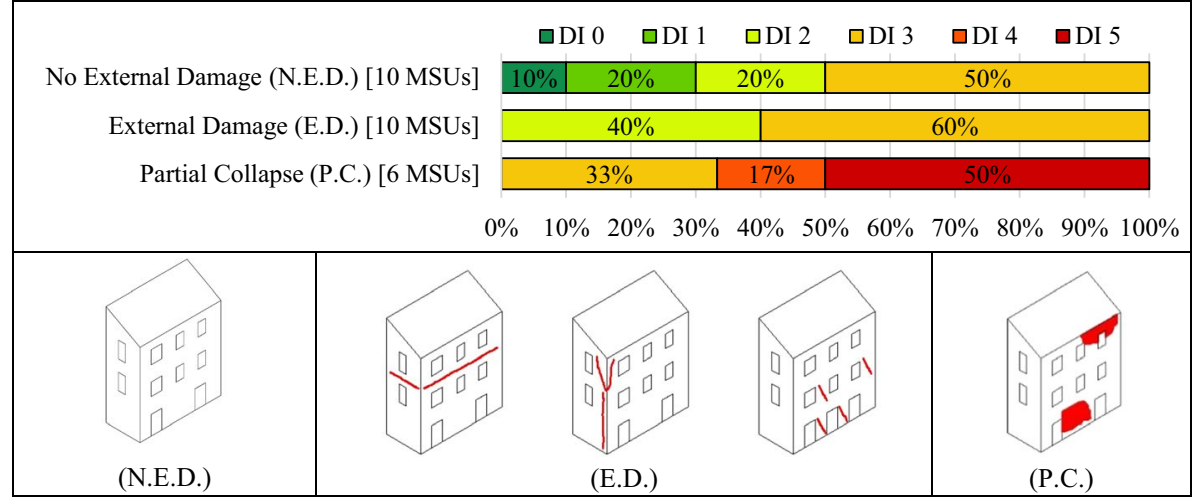

Fig. 17 Damage Index distribution on MSUs located in Campi Alto

involved all the walls. Moreover, the architectural restriction of maintaining the fair-faced aspect of the masonry forced to apply R.P. only on the internal side of the external walls.

The intervention on horizontal structures involved, in all cases, the strengthening of existing vaults through the removal of the filling material and the construction of a $\mathrm{RC}$ slab at the extrados. Furthermore, existing wooden slabs were always replaced by new ones made of: RC beams and hollow bricks ( 9 projects); new wood beams (4 projects); steel beams ( 1 projects); or a combination of the previous ones ( 5 projects). The existing roofs were in most cases replaced by RC structures or wooden beams (10 and 7 projects, respectively), by steel beams in 2 projects. The new horizontal structures were connected to the surrounding walls by a RC ring beam partially built in the masonry wall thickness (or with the same wall dimension in case of demolition and reconstruction).

In the N.E.D. group, 3 MSUs had a damage index equal to 0 or 1, see Fig. 18. Although different in size and number of floors, a common factor on such MSUs was the extensive
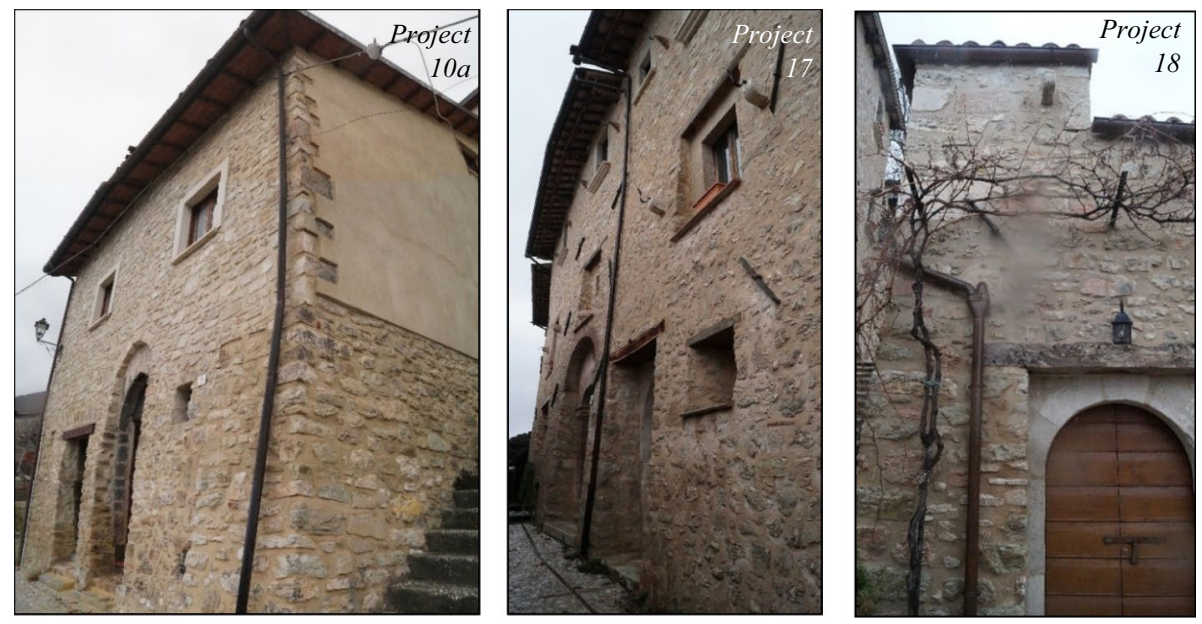

Fig. 18 MSUs, located in Campi Alto, with no external damage and damage index equal to 0 (project 18) or 1 (projects 10 and 17) 
use of strengthening intervention on vertical walls. In particular, the walls that suffered severe damage after the 1979 and 1997 earthquakes were restored by means of several local dismantling and subsequent rebuilding (the so-called "scuci-cuci" intervention), and strengthened through G.I. or combining G.I. and R.P. (e.g. project 10, see Annex). Connections between orthogonal walls were improved by inserting S.C. or T.R. (e.g. project 17 and 18, see Annex). Furthermore, a strong replacement of existing walls was carried out by using block masonry (project 10a) or stone masonry (project 17). Thus, extensive intervention on both vertical and horizontal structures clearly led to satisfactory seismic performances of the MSUs. In the remaining 7 MSUs, the damage index resulted in the range of $2-3$, however the lack of visible damage prevents understanding the problems that affected these buildings.

In the E.D. group (i.e. $10 \mathrm{MSUs}$ ) the damage index resulted always equal or greater than 2; in 5 MSUs, horizontal cracks, mainly localized at the level of intermediate floors, were detected (see Fig. 19).

Even if the width of the cracks was millimetric, the cracks affect the entire wall thickness and develop along the entire perimeter of the building, revealing the activation of mutual translation between the two portions of the building, above and below the crack. This type of damage was detected on buildings where the upper floors were completely rebuilt, and the cracks were localized on the contact surface between the new floors and the existing ones. The behaviour of such buildings clearly confirms that, in case of reconstruction of floors, it is crucial to properly connect the new floors to the existing ones and vertical structures to horizontal ones. Indeed, in such 5 MSUs the poor attention to details in the adopted strengthening solution was the main reason of the damage detected after the earthquake.

In the remaining 5 MSUs with external damage, the damage was caused by deficiencies correlated to the original vulnerability of the building which were unsolved by renovation works: lack of connections on orthogonal walls and insufficient use of steel connectors as a strengthening technique, (see Fig. 20 related to MSU of project 13); reduced distance between openings and/or presence of openings close to the corners of the building and insufficient use of strengthening aimed at increasing the vertical walls bearing capacity, (see Fig. 21 related to MSUs of projects 6 and 7). In this latter case, MSUs belonging to a row building (adjacent masonry structural units related to each other) reported damages localized at its far end. By analysing the ground floor plan (Fig. 21a), it can be noted that the openings are very close to the corners and the
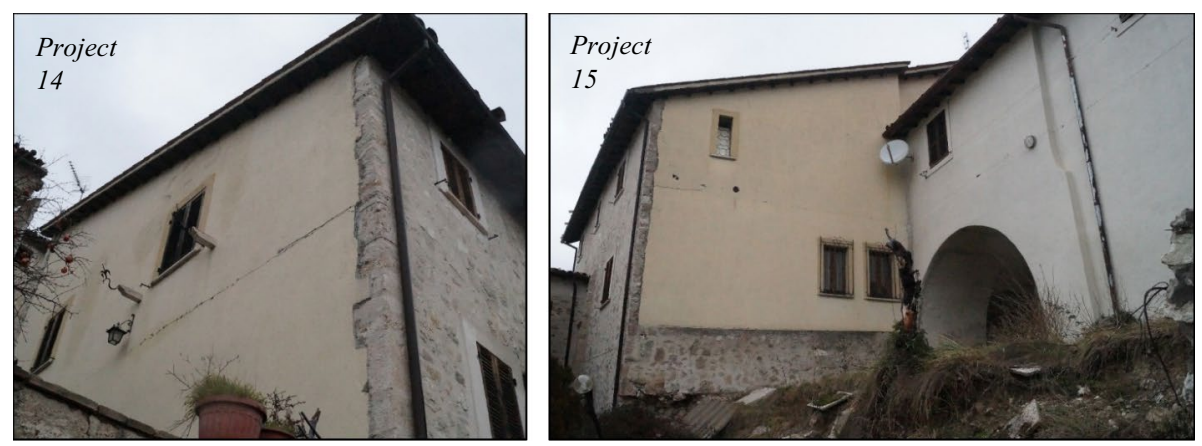

Fig. 19 Common horizontal cracks at floor level of MSUs located in Campi Alto 
a

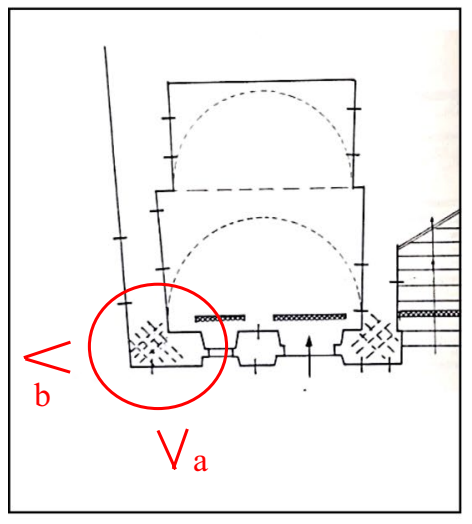

b

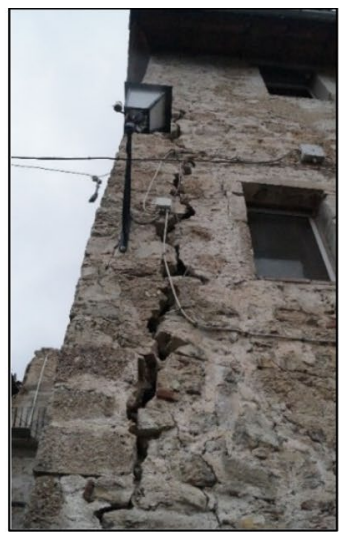

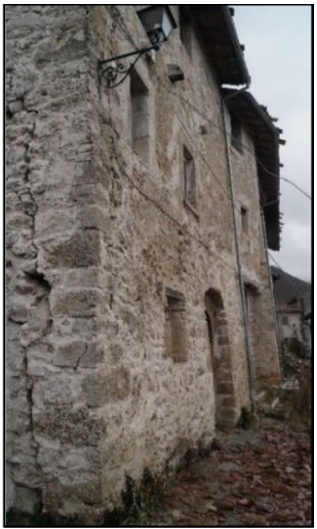

Fig. 20 Project 13: poor connection of orthogonal bearing walls of a MSU located in Campi Alto

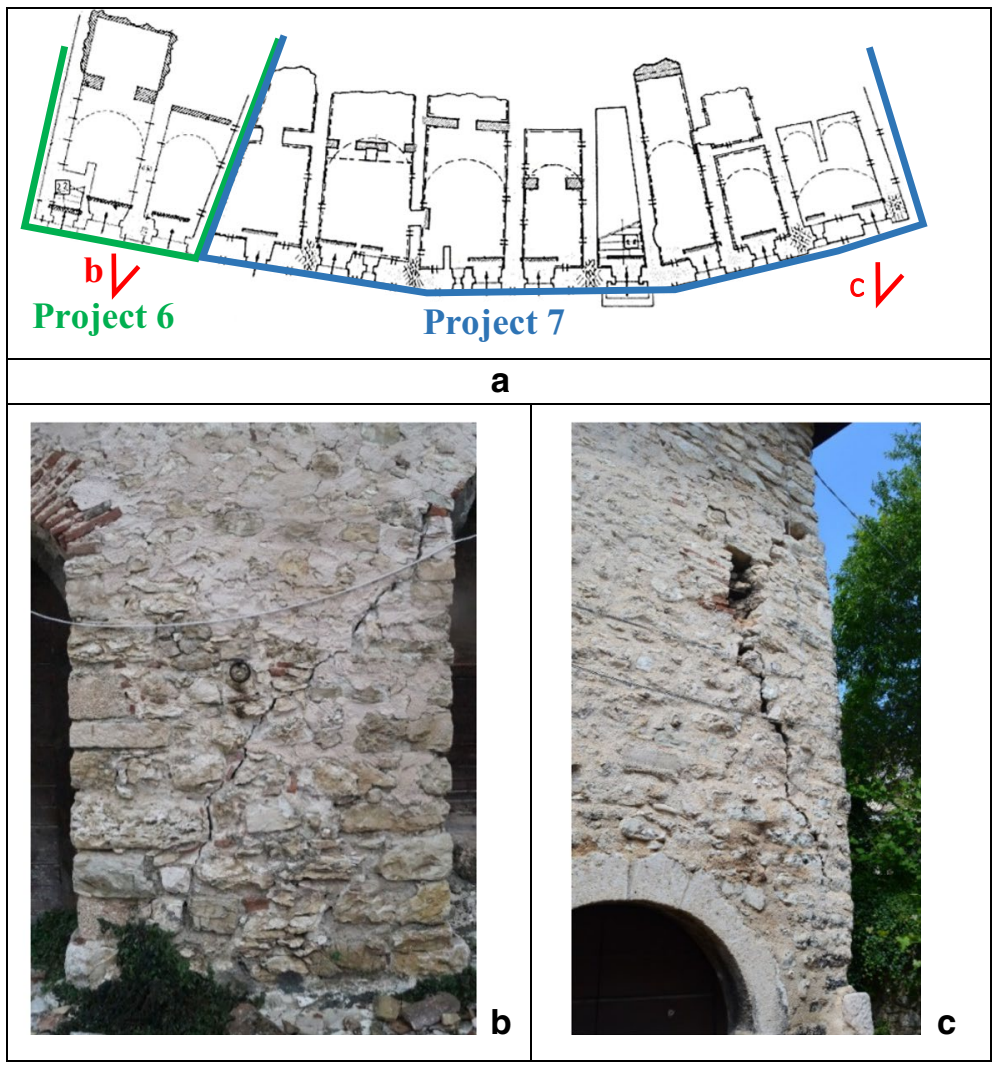

Fig. 21 Projects 6 and 7 (Campi Alto): a MSUs ground floor plan. b-c Damage at the far end of the row building 
distance between openings is very small; these two features cause a lack of masonry area that led to the formation of shear cracks in two bearing walls (Fig. 21b, c).

The P.C. group involved 6 MSUs with a damage index ranging between 3 and 5. In all cases the bad quality of masonry led to partial collapses. In particular, the uncomplete replacement of original existing wall in the strengthening interventions designed after 1979 seismic events led to partial collapse of ground floor with limited damage on the upper ones. In particular, the load-bearing walls of the first, second and third floors were demolished and rebuilt with block masonry while ground floor vertical walls were strengthened by G.I. in project 4, see Annex A and Fig. 22. After the 2016 seismic sequence the building experienced a rigid rotation of the three upper floors (with no damage, Fig. 22a) with respect to the ground floor where a large portion of the façade collapsed (Fig. 22b). Thus, the G.I. on ground floor resulted ineffective or insufficient to improve the quality of the masonry at the ground floor and this, along with the presence of two too wide openings in relation to the wall dimension, led to the crumbling of the wall; tie rods were clearly ineffective because of poor quality of masonry wall. Similarly, the masonry at left corner of ground and first floor crumbled due to masonry bad quality in the MSUs of project 8 (see Fig. 23a); also the upper floors suffered damages limited to the walls that were not rebuilt after 1979 seismic events. In the MSU of project 2 an extensive collapse was detected: the original stone masonry of the ground floor and first floor crumbled (Fig. 23b); in addition, the external layer of stone masonry, applied only for aesthetic reasons, collapsed due to the lack of connections with the load-bearing block masonry behind it.

Severe damage after the 2016 sequence was also observed in case of MSUs strengthened by using a very heavy and rigid roof on a bad quality walls which were not adequately reinforced by extensive use of G.I. and R.P. as originally designed, (e.g. MSU of project 11, see Annex A and Fig. 24).

The collapses observed in Campi Alto were mainly caused by poor masonry quality. No out-of-plain mechanisms of wall panels were observed, this is certainly due to the positive action of spurs and buttresses built after the 1859 earthquake and to the insertion of tie rods and the improvement of the connections between orthogonal wall and vertical and horizontal structures carried out in the most recent interventions.

a

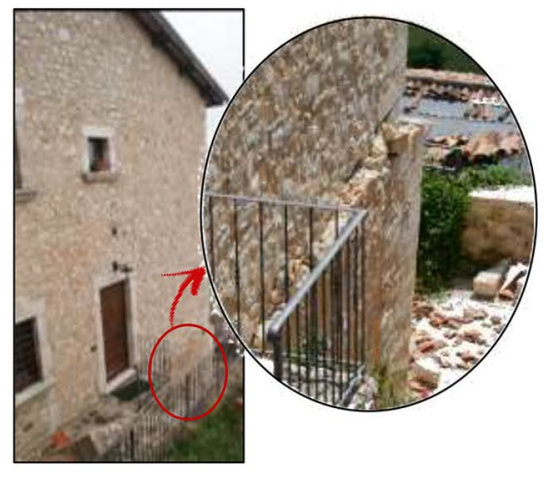

b

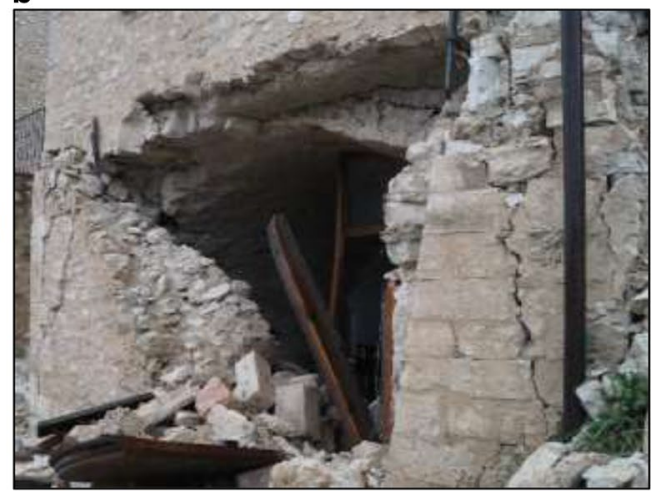

Fig. 22 Project 4 (Campi Alto): a rigid rotation of replaced floors with respect to the ground floor; b crumble and collapse of poor masonry wall at ground floor 
a

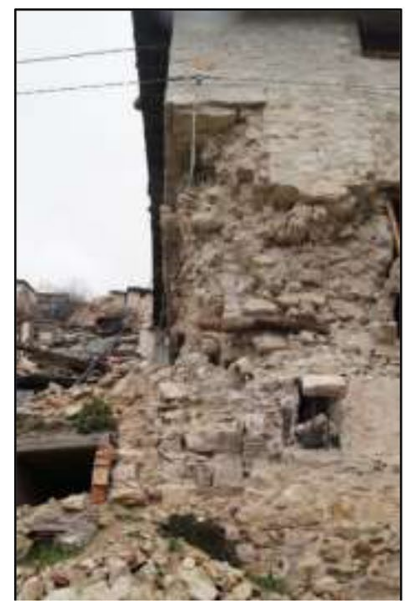

b

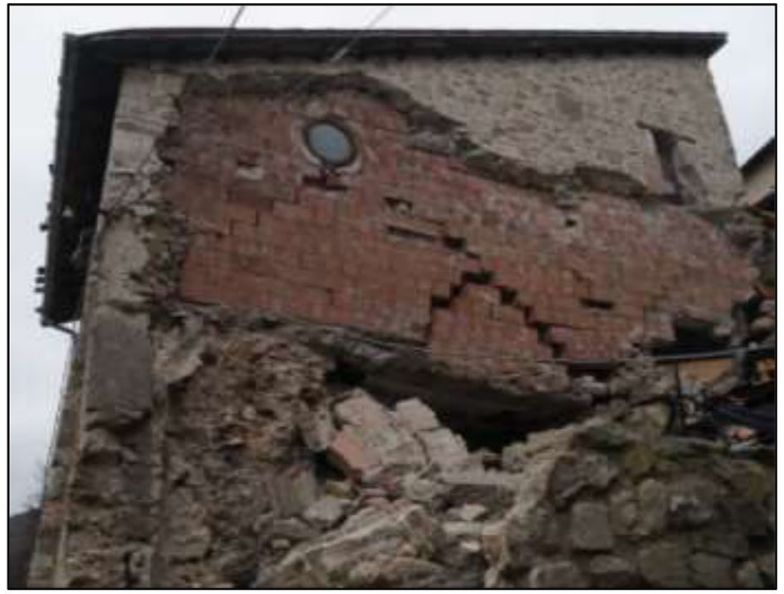

Fig. 23 a Project 8 (Campi Alto): crumble of masonry walls at ground floor; b Project 2: collapse of the masonry walls at ground and first floor

a

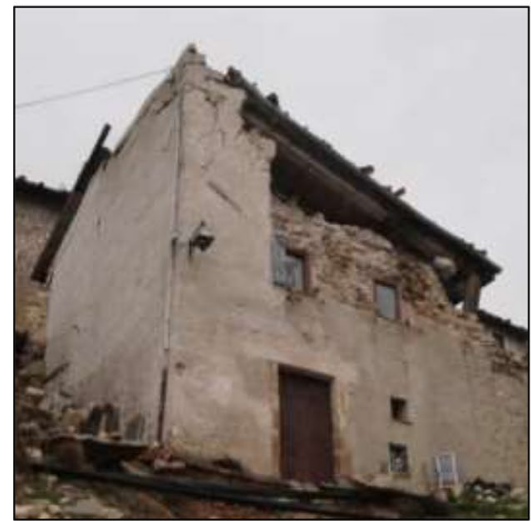

b

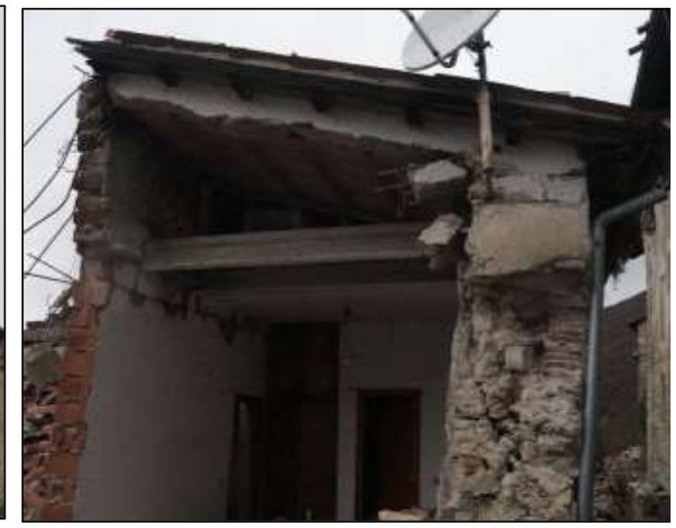

Fig. 24 Project 11 (Campi Alto): collapse of poor quality masonry walls due to the presence of heavy roof: a downstream façade; $\mathbf{b}$ lateral section 


\section{Conclusion}

The study analyses the response of buildings in Campi Alto after the 2016 seismic sequence. A large part of these buildings was strengthened in the past 30 years following previous earthquakes which occurred in 1979 and 1997. The empirical damage detected on these buildings according to the visual inspections carried out after the 2016 seismic sequence, showed that the behaviour of buildings in Campi Alto was not satisfactory.

The behaviour of buildings in Campi Alto are compared with that of the buildings in the nearby historic centre of Norcia. In this case, the interventions carried out in the recent past resulted effective to strongly reduce the damage (Sisti et al. 2018).

The analysis of the seismic input allowed to exclude that such different behaviour was due to a significant variation of the excitation: the seismic intensity parameters recorded during the two earthquakes occurred on 26th October 2016 by the accelerometric station near Campi Alto (CMI) were comparable with those recorded during the earthquake of 30th October 2016 by stations located near Norcia (NOR and NRC). In addition, the microzonation studies exclude that Campi Alto was subjected to a major amplification due to morphology. As a result, the main reason of the different behaviour may be related to three factors: the original vulnerability of buildings (i.e. buildings in Campi Alto are mostly irregular in elevation due to the area orography); the masonry quality (i.e. many buildings in Campi Alto have poorer masonry quality with respect to buildings in Norcia and they have fair faced stone walls while most of those in Norcia are plastered and this has made possible in the past to apply more invasive strengthening techniques like as reinforced plaster on both wall sides); the insufficient effectiveness, in some cases, of strengthening interventions executed after past seismic events. To better investigate on such latter aspect, 20 projects of strengthening interventions submitted to the Civil Engineering Department of the Umbria Region between 1984 and 2012 have been herein analysed and discussed. The analyses of such projects along with the evaluation of the empirical damage detected after the recent seismic sequence represented a unique opportunity to investigate on the effectiveness of past strengthening solutions. The projects involved 26 structural units of Campi Alto corresponding to $53 \%$ of the entire built-up area of Campi Alto; thus, the outcome of the analysis may be assumed reasonably representative of the strengthening works carried out in Campi Alto.

The study showed that a very low damage level (50\% of buildings with a damage index lower than 2 and the remaining 50\% with a damage index equal to 3) was achieved in case of extensive interventions on both vertical and horizontal structures. Although a seismic input with $\mathrm{S}_{\mathrm{a}}$ ranging between 1193 and $1572 \mathrm{~cm} / \mathrm{s}^{2}$ (for structural periods $\mathrm{T}=0.1-0.5 \mathrm{~s}$ ) was recorded on buildings in Campi Alto, the reconstruction of walls that suffered severe damage after the 1979 and 1997 earthquakes combined with the strengthening of the 
remaining walls through grout injections or combining grout injections and reinforced plaster as well as the proper use of connections between orthogonal walls led to very satisfactory seismic behaviour. By contrast, significant damage was detected on buildings where the upper floors were rebuilt in block masonry while the ground floor was not adequately strengthened. Indeed, the absence of strengthening solution at ground floor, mainly related to preservation issues led to unsolved deficiencies like as insufficient masonry mechanical strength. This clearly point out the need of advances in low impact solution and intervention to reduce the vulnerability of constructions preserving their original characteristics. In this field local strengthening intervention and innovative materials may represent a viable and sound solution.

Furthermore, the reconstruction of entire floors needs to be accomplished by strong attention on the use of proper connections between new and existing floors in order to avoid the presence of horizontal cracks at the floors interface. This crack pattern reveals a lack of connection between the new horizontal structures and vertical ones (new or existing) and suggests adopting appropriate solutions if similar intervention is carried out in future applications.

When external walls were rebuilt in block masonry and an outer cover of stone masonry is built for aesthetic reasons it is necessary to carefully connect this layer with the loadbearing block masonry behind it otherwise collapses may occur.

Reduced distance between openings and presence of openings close to the corners of the building strongly affected the performance of MSUs by reducing their in plane seismic capacity; a strong and diffuse use of in plane strengthening solution should be used in such situations.

The use of connectors at building corners is crucial to avoid significant damage and collapses and they should be adequately designed (i.e. number, length). Finally, the realization of new heavy roof should be accomplished by strong intervention aimed at increasing the mechanical properties of bearing walls or it can resulted detrimental for the MSU seismic performances.

\section{Appendix}

See (Table 3). 
Table 3 The table summarizes the main characteristics of 26 projects realized in Campi Alto between 1984 and 2012

\begin{tabular}{|c|c|c|c|c|c|c|c|c|c|}
\hline \multirow{3}{*}{ 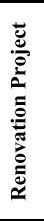 } & \multirow{3}{*}{ 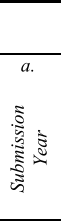 } & \multirow{3}{*}{ 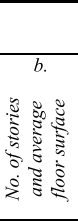 } & \multicolumn{2}{|c|}{$\begin{array}{l}\text { Vertical } \\
\text { structures }\end{array}$} & \multicolumn{3}{|c|}{$\begin{array}{l}\text { Horizontal } \\
\text { structures }\end{array}$} & \multicolumn{2}{|c|}{$\begin{array}{l}\text { Post-earthquake } \\
\text { empirical damage }\end{array}$} \\
\hline & & & $\begin{array}{c}c . \\
\text { Replacement } \\
\text { of existing } \\
\text { walls }\end{array}$ & $\begin{array}{l}\text { d. } \\
\text { Strengthening } \\
\text { interventions } \\
\text { on remaining } \\
\text { walls }\end{array}$ & $\begin{array}{c}e . \\
\text { Replacement } \\
\text { of floors }\end{array}$ & $\begin{array}{c}f . \\
\text { Replacement or } \\
\text { strengthening of } \\
\text { vaults }\end{array}$ & $\begin{array}{c}g . \\
\text { Replacement } \\
\text { of roof }\end{array}$ & $\begin{array}{c}h . . \\
\text { Damage } \\
\text { index }\end{array}$ & $\begin{array}{c}i . \\
\text { Type of } \\
\text { external } \\
\text { damage }\end{array}$ \\
\hline & & & Floor (extent) & $\begin{array}{c}\text { Type } \\
\text { (extent) }\end{array}$ & $\begin{array}{c}\text { Type } \\
\text { (extent) }\end{array}$ & $\begin{array}{c}\text { Type } \\
\text { (extent) }\end{array}$ & $\begin{array}{c}\text { Type } \\
\text { (extent) }\end{array}$ & & \\
\hline 18 & 2012 & $\begin{array}{c}1 \\
50 \mathrm{~m}^{2}\end{array}$ & - & 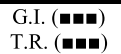 & - & R.V. (घ口u) & - & 0 & N.E.D. \\
\hline 17 & 2003 & $\begin{array}{c}4 \\
163 \mathrm{~m}^{2}\end{array}$ & $\begin{array}{c}2(\mathbf{\square \square}) \\
3-4(\mathbf{\square})^{*}\end{array}$ & 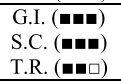 & $\begin{array}{l}\mathrm{RC}(\boldsymbol{\square}) \\
\mathrm{W}(\boldsymbol{\square})\end{array}$ & S.RC S. (mm) & W & 1 & N.E.D. \\
\hline $10 \mathrm{a}$ & 2010 & $\begin{array}{c}3 \\
35 \mathrm{~m}^{2}\end{array}$ & $2-3(\mathbf{m m})$ & $\begin{array}{l}\text { G.I. (घma) } \\
\text { R.P. (घma) }\end{array}$ & $\mathrm{RC}(\boldsymbol{m} \mathbf{m})$ & S.RC S. (mm) & W & 1 & N.E.D. \\
\hline 12 & 1989 & $\begin{array}{c}4 \\
70 \mathrm{~m}^{2}\end{array}$ & 3-4 (घ口प) & $\begin{array}{l}\text { G.I. (man) } \\
\text { S.C. (man) }\end{array}$ & RC ( $\mathbf{m} \mathbf{m})$ & S.RC S. (mma) & $\mathrm{RC}$ & 2 & N.E.D. \\
\hline 19 & 1993 & $\begin{array}{c}3 \\
109 \mathrm{~m}^{2}\end{array}$ & $2(\square \square \square)$ & G.I. (घ口๐) & W (ma) & S.RC S. (ma) & W & $\begin{array}{l}3 \\
2\end{array}$ & N.E.D. \\
\hline 20 & 2008 & $\begin{array}{c}3 \\
41 \mathrm{~m}^{2}\end{array}$ & $2-3(\square m a)$ & $\begin{array}{l}\text { G.I. (घघu) } \\
\text { R.P. (घ口u) }\end{array}$ & S ( $\mathbf{m} \mathbf{m})$ & S.RC S. (mma) & $S$ & 3 & N.E.D. \\
\hline 1 & 1991 & $\begin{array}{c}3 \\
93 \mathrm{~m}^{2} \\
\end{array}$ & 2-3 (घ口) & G.I. (ロn⿴囗十) & $\mathrm{RC}(\mathbf{m} \mathbf{m})$ & S.RC S. (mm) & $\mathrm{RC}$ & 3 & N.E.D. \\
\hline 3 & 2000 & $\begin{array}{c}3 \\
70 \mathrm{~m}^{2} \\
\end{array}$ & $2-3(\mathbf{m} \mathbf{m})^{\diamond}$ & G.I. (man) & RC (ma) & S.RC S. (man) & W & 3 & N.E.D. \\
\hline 16 & 1990 & $\begin{array}{c}4 \\
278 \mathrm{~m}^{2}\end{array}$ & $\begin{array}{l}1-2(\square \square \square) \\
3-4(\square \square \square)\end{array}$ & 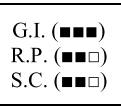 & RC ( $\mathbf{m a})$ & S.RC S. (man) & $\mathrm{RC}$ & $\begin{array}{l}3 \\
2 \\
2 \\
3\end{array}$ & $\begin{array}{c}\text { N.E.D. } \\
\text { E.D } \\
\text { E.D } \\
\text { E.D. }\end{array}$ \\
\hline $10 \mathrm{~b}$ & 2010 & $\begin{array}{c}3 \\
11 \mathrm{~m}^{2}\end{array}$ & $2-3(\square \square)$ & 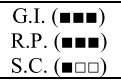 & $\mathrm{RC}(\mathbf{m} \mathbf{m})$ & S.RC S. (mm) & W & 3 & E.D. \\
\hline 15 & 1988 & $\begin{array}{c}2 \\
33 \mathrm{~m}^{2} \\
\end{array}$ & $\begin{array}{l}1(\mathbf{m a}) \\
2(\square \square)\end{array}$ & $\begin{array}{l}\text { G.I. }(\square \square) \\
\text { S.C. }(\square \square)\end{array}$ & RC ( $\mathbf{m} \mathbf{m})$ & S.RC S. (mma) & $\mathrm{RC}$ & 2 & E.D. \\
\hline 14 & 1996 & $\begin{array}{c}3 \\
60 \mathrm{~m}^{2} \\
\end{array}$ & 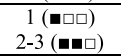 & $\begin{array}{l}\text { G.I. (घघa) } \\
\text { S.C. (घma) }\end{array}$ & RC ( $\mathbf{m} \mathbf{m})$ & S.RC S. (man) & $\mathrm{RC}$ & 3 & E.D. \\
\hline 9 & 2002 & $\begin{array}{c}3 \\
25 \mathrm{~m}^{2} \\
\end{array}$ & - & G.I. ( $\square \square)$ & W (ma) & S.RC S. (man) & W & 2 & E.D. \\
\hline 6 & 1984 & $\begin{array}{c}3 \\
67 \mathrm{~m}^{2}\end{array}$ & $1-2-3$ (마) & 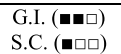 & W (ma) & S.RC S. (man) & $\mathrm{RC}$ & 3 & E.D. \\
\hline 7 & 1989 & $\begin{array}{c}3 \\
196 \mathrm{~m}^{2}\end{array}$ & $1-2-3$ (घ口व) & 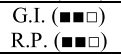 & $\begin{array}{l}\mathrm{RC}\left(\mathbf{\square}^{\prime}\right) \\
\mathrm{W}(\boldsymbol{\square})\end{array}$ & S.RC S. (mघ) & $\mathrm{RC}$ & 3 & E.D. \\
\hline 13 & 1993 & $\begin{array}{c}3 \\
121 \mathrm{~m}^{2} \\
\end{array}$ & $3(\mathbf{m})$ & $\begin{array}{l}\text { G.I. (mm) } \\
\text { S.C. }(\mathbf{m})\end{array}$ & $\begin{array}{l}\text { RC (घ口) } \\
\text { W (घ口) }\end{array}$ & S.RC S. (mm) & $\mathrm{RC}$ & 3 & E.D. \\
\hline 4 & 2005 & $\begin{array}{c}4 \\
36 \mathrm{~m}^{2}\end{array}$ & $\begin{array}{c}2(\square \square) \\
3-4(\square \square)\end{array}$ & $\begin{array}{l}\text { G.I. (घघa) } \\
\text { T.R. (घघa) }\end{array}$ & $\begin{array}{l}\mathrm{RC}(\boldsymbol{m}) \\
\mathrm{W}(\boldsymbol{\square \square})\end{array}$ & S.RC S. (man) & $\mathrm{S}$ & $3^{*}$ & P.C. \\
\hline 5 & 2014 & $\begin{array}{c}3 \\
85 \mathrm{~m}^{2} \\
\end{array}$ & $\begin{array}{c}1\left(\mathbf{\square}()^{\dagger}\right. \\
2-3(\square \square)\end{array}$ & S.C. (man) & W (man) & S.RC S. (mma) & W & 3 & P.C. \\
\hline 8 & 1986 & $\begin{array}{c}3 \\
132 \mathrm{~m}^{2}\end{array}$ & $\begin{array}{c}1-2(\square \square \square) \\
3(\square \square)\end{array}$ & 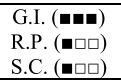 & $\begin{array}{l}\mathrm{RC}(\boldsymbol{\square}) \\
\mathrm{W}(\boldsymbol{\square \square})\end{array}$ & S.RC S. (mma) & $\mathrm{RC}$ & $\begin{array}{l}5 \\
4\end{array}$ & $\begin{array}{l}\text { P.C. } \\
\text { P.C: }\end{array}$ \\
\hline 2 & 1992 & $\begin{array}{c}3 \\
81 \mathrm{~m}^{2}\end{array}$ & $\begin{array}{l}1(\mathbf{\square \square}) \\
2(\mathbf{\square \square}) \\
3(\mathbf{\square})\end{array}$ & 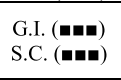 & $\mathrm{RC}(\mathbf{m} \mathbf{m})$ & S.RC S. (man) & $\mathrm{RC}$ & 5 & P.C. \\
\hline 11 & 1992 & $\begin{array}{c}3 \\
36 \mathrm{~m}^{2}\end{array}$ & $3(\mathbf{m})$ & 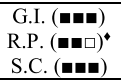 & $\mathrm{RC}(\mathbf{m} \mathbf{m})$ & S.RC S. (mm) & $\mathrm{RC}$ & 5 & P.C. \\
\hline
\end{tabular}

Extent $e(e<1 / 3: \square \square \square ; 1 / 3 \leq e<2 / 3: \square \square ; e \geq 2 / 3: \mathbf{\square} \square)$

*The external walls were rebuilt in stone masonry, the internal ones in block masonry.

The walls were rebuilt in concrete blocks masonry.

†The walls were rebuilt in stone masonry.

The ground floor is partly collapsed, while the upper floors are intact (the damage level is coherent whit the AeDES criteria but in this case underrates the actual state of the building).

Columns Notation list: Column d: G.I.=Grout Injections; R.P.=Reinforced Plaster jacketing; S.C. = Steel Connectors; T.R. $=$ Tie Rods

Columns e,g: $\mathrm{RC}=\mathrm{RC}$ beams and hollow bricks; $\mathrm{S}=$ Steel beams; $\mathrm{W}=$ Wooden beams; 
Table 3 (continued)

Column f: R.V. = Replacement of Vaults; S. RC S. = Strengthening with RC Slab at Vaults' extrados

Column $i$ : N.E.D. $=$ No External Damage; E.D. $=$ External Damage; P.C. $=$ Partial Collapse

Acknowledgements This study was performed within the framework of PE 2019-2021, the joint program DPC-ReLUIS. The authors would like to acknowledge the technicians of the Seismic Risk Office of Umbria and Andrea Zaroli. Special thanks are owed to Alessandro De Maria.

Funding Open access funding provided by Università degli Studi di Napoli Federico II within the CRUICARE Agreement.

Open Access This article is licensed under a Creative Commons Attribution 4.0 International License, which permits use, sharing, adaptation, distribution and reproduction in any medium or format, as long as you give appropriate credit to the original author(s) and the source, provide a link to the Creative Commons licence, and indicate if changes were made. The images or other third party material in this article are included in the article's Creative Commons licence, unless indicated otherwise in a credit line to the material. If material is not included in the article's Creative Commons licence and your intended use is not permitted by statutory regulation or exceeds the permitted use, you will need to obtain permission directly from the copyright holder. To view a copy of this licence, visit http://creativecommons.org/licenses/by/4.0/.

\section{References}

Baggio C, Bernardini A, Colozza R, Coppari S, Corazza L, Della Bella M, Di Pasquale G, Dolce M, Goretti A, Martinelli A, Orsini G, Papa F, Zuccaro G (2007) Field manual for post-earthquake damage and safety assessment and short term countermeasures (AeDES), European commission, Joint research centre institute for the protection and security of the citizen, European communities, 2007.

Binda L, Cardani G, Saisi A, Valluzzi MR (2006) Vulnerability analysis of the historical buildings in seismic area by a multilevel approach. Asian J Civil Eng (Build Hous) 7(4):343-357

Binda L, Cardani G, Saisi A, Valluzzi MR, Munari M, Modena C (2007) Multilevel approach to the vulnerability analysis of historic buildings in seismic areas - Part 1: detection of parameters for the vulnerability analysis through on site and laboratory investigations". Int J Restor Build Monum/Int Zeitschrift für Bauinstand Baudenkm 13(6):413-426

Borri A, Sisti R, Prota A, Di Ludovico M, (2018) La risposta strutturale degli edifici ordinari del centro storico di Norcia alla sequenza sismica del 2016, Structural 2016. https://doi.org/10.12917/STRU216. 07 (in Italian)

Boschi E, Guidoboni E, Ferrari G, Valensise G (1998) I terremoti dell'Appennino umbro-marchigiano - area sud-orientale dal 99 a.C. al 1984, Editrice Compositori. Bologna, ISBN: 88-7794-154-5 (in Italian)

Callisto L, Ricci C (2019) Interpretation and back-analysis of the damage observed in a deep tunnel after the 2016 Norcia earthquake in Italy. Tunn Undergr Space Technol. https://doi.org/10.1016/j.tust.2019.04. 012

Chiaraluce L, Di Stefano R, Tinti E (2017) The 2016 Central Italy seismic sequence: a first look at the mainshocks, aftershocks, and source models. Seismol Res. https://doi.org/10.1785/0220160221

D'Altri AM, Castellazzi G, de Miranda S (2018) Collapse investigation of the Arquata del Tronto medieval fortress after the 2016 Central Italy seismic sequence. J Build Eng. https://doi.org/10.1016/j.jobe.2018. 03.021

Di Ludovico M, Disgrisolo A, Moroni C, Graziotti F, Manfredi V, Prota A, Dolce M, Manfredi G (2018) Remarks on damage and response of school buildings after the Central Italy earthquake sequence. Bull Earthq Eng. https://doi.org/10.1007/s10518-018-0332-X

Dolce M, Speranza E, Giordano F, Borzi B, Bocchi F, Conte C, Di Meo A, Faravelli M, Pascale V (2019) Observed damage database of past Italian earthquakes: the Da. D.O. WebGIS. Bollettino di Geofisica Teorica ed Applicata 60(2):141-164. https://doi.org/10.4430/bgta0254

Fiorentino G, Forte A, Pagano E, Sabetta F, Baggio C, Lavorato D, Nuti C, Santini S (2018) Damage patterns in the town of Amatrice after August 24th, 2016 Central Italy earthquakes. Bull Earthquake Eng. https://doi.org/10.1007/s10518-017-0254-z

Gara F, Regni M, Carbonari S, Balducci A, Dezi L (2017) Dynamic behaviour of a retrofitted school building subjected to the after-shock sequence of the 2016 Central Italy earthquake, X International conference on structural dynamics, EURODYN 2017. Proc Eng 199: 2084-2089 
Gautam D, Chaulagain H (2016) Structural performance and associated lessons to be learned from world earthquakes in Nepal after 25 April 2015 (MW 7.8) Gorkha earthquake. Eng Failure Anal. https:// doi.org/10.1016/j.engfailanal.2016.06.002

Grünthal G (ed) (1998) European macroseismic scale 1998. European Seismological Commission, sub commission on Engineering Seismology, Working Group Macroseismic Scales. Conseil de 1'Europe, Cahiers du Centre Européen de Géodynamique et de Séismologie, Vol 15. Luxembourg

Hofer L, Zampieri P, Zanini MA, Faleschini F, Pellegrino C (2018) Seismic damage survey and empirical fragility curves for churches after the August 24, 2016 Central Italy earthquake. Soil Dyn Earthq Eng. https://doi.org/10.1016/j.soildyn.2018.02.013

Housner GW (1952) Spectrum intensities of strong-motion earthquakes. Symposium on earthquake and blast effects on structures, Los Angeles, California, USA, pp 20-36

Iervolino I, Baltzopoulos G, Chioccarelli E, Suzuki A (2019) Seismic actions on structures in the nearsource region of the 2016 central Italy sequence. Bull Earthquake Eng. https://doi.org/10.1007/ s10518-017-0295-3

Jahromi SG, Karkhaneh S (2019) The plurality effect of topographical irregularities on site seismic response. Earthq Eng Eng Vib. https://doi.org/10.1007/s11803-019-0519-4

Lanzo G, Tommasi P, Ausilio E, Aversa S, Bozzoni F, Cairo R, d'Onofrio A, Durante MG, Foti S, Giallini S, Mucciacciaro M, Pagliaroli A, Sica S, Silvestri F, Vessia G, Zimmaro P (2019) Reconnaissance of geotechnical aspects of the 2016 Central Italy earthquakes. Bull Earthquake Eng. https:// doi.org/10.1007/s10518-018-0350-8

Luzi L, Puglia R, Russo E \& ORFEUS WG5 (2016) Engineering strong motion database. Istituto Nazionale di Geofisica e Vulcanologia. Observ Res Facil Euro Seismol. https://doi.org/10.13127/ESM

Mouyiannou A, Penna A, Rota M, Graziotti F, Magenes G (2014) Implications of cumulated seismic damage on the seismic performance of unreinforced masonry buildings. Bull New Zealand Soc Earthq Eng 47(2):157-170

Ortega J, Vasconcelos G, Rodrigues H, Correira M, Lourenço PB (2017) Traditional earthquake resistant techniques for vernacular architecture and local seismic cultures: a literature review. J Cultur Heritag. https://doi.org/10.1016/j.culher.2017.02.015

Panzera F, Lombardo G, Imposa S, Grassi S, Gresta S, Catalano S, Romagnoli G, Tortorici G, Patti F, Di Maio E (2018) Correlation between earthquake damage and seismic site effects: the study case of Lentini and Carlentini Italy. Eng Geol 240(2018):149-162

Penna A, Calderini C, Sorrentino L, Carocci C, Cescatti E, Sisti R, Borri A, Modena C, Prota A (2019) Damage to churches in the 2016 central Italy earthquakes. Bull Earthquake Eng. https://doi.org/10. 1007/s10518-019-00594-4

Poiani M, Gazzani V, Clementini F, Milani G, Valente M, Lenci S (2018) Iconic crumbling of the clock tower in Amatrice after 2016 central Italy seismic sequence: advanced numerical insight International conference on building pathology and constructions repair - CINPAR 2018

Putrino V, D'Ayala D (2019a) Effectiveness of seismic strengthening to repeated earthquakes in historic urban contexts: norcia 2016. Disaster Prev Manag Int J 29(2019):47-64. https://doi.org/10.1108/ DPM-07-2018-0230

Putrino V, D'Ayala D (2019b) Norcia and Amatrice. A comparison of the two historic centres' performance under the central Italy earthquake sequence. In: Proceedings of the 7th ECCOMAS thematic conference on computational methods in structural dynamics and earthquake engineering. COMPDYN 2019: Crete, Greece, pp 2636-2648

Reale C, Scheibel B, Vignoli F, Decanini L, Sorrentino L (2004) Il Regolamento edilizio di Norcia del 1860: fra storia sismica e storia urbanistica. In L'ingegneria sismica in Italia, proceeding of 11th national conference, Genova 25-29 gennaio 20114. Padova (in Italian).

Regione Umbria (1981) Technical provisions and methodology for repair and strengthening works of buildings damaged by earthquake (art. 38 L:R. 1/7/81 n. 34) - Regione dell'Umbria, Direttive tecniche ed esemplificazione delle metodologie di interventi per la riparazione ed il consolidamento degli edifici danneggiati da eventi sismici (art. 38 L:R. 1/7/81 n. 34) (in Italian)

Rovida A, Locati M, Camassi R, Lolli B, Gasperini P (2019) Italian parametric earthquake catalogue (CPTI15), version 2.0. Istituto Nazionale di Geofisica e Vulcanologia (INGV). https://doi.org/10. 13127/CPTI/CPTI15.2

Sayın E, Yon B, Calayır Y, Karaton M (2013) Failures of masonry and adobe buildings during the June 23, 2011 Maden-(Elazı $\breve{g})$ earthquake in Turkey. Eng Fail Anal. https://doi.org/10.1016/j.engfailanal.2012. 10.016

Sisti R, Di Ludovico M, Borri A, Prota A (2018) Damage assessment and the effectiveness of prevention: the response of ordinary unreinforced masonry buildings in Norcia during the Central Italy 2016-2017 seismic sequence. Bull Earthquake Eng. https://doi.org/10.1007/s10518-018-0448-z 
Sorrentino L, Cattari S, da Porto F, Magenes G, Penna A (2018) Seismic behaviour of ordinary masonry buildings during the 2016 Central Italy Earthquakes. Bull Earthquake Eng. https://doi.org/10.1007/ s10518-018-0370-4

Steimen S, Fäh D, Giardini D, Bertogg M, Tschudi S (2004) Reliability of building inventories in seismic prone regions. Bull Earthquake Eng 2:361-388. https://doi.org/10.1007/s10518-004-3806-y

Publisher's Note Springer Nature remains neutral with regard to jurisdictional claims in published maps and institutional affiliations. 